\title{
Organic geochemical characteristics of black shales across the Ordovician-Silurian boundary in the Holy Cross Mountains, Central Poland
}

\author{
Karwan A. Mustafa, ${ }^{a, b}$, Mark A. Sephton ${ }^{a}$, Jonathan S. Watson ${ }^{a}$, Fivos Spathopoulos ${ }^{a}$, Piotr Krzywiec ${ }^{c}$ \\ ${ }^{a}$ Department of Earth Science and Engineering, Imperial College London, South Kensington Campus, London SW7 2AZ, UK \\ b Department of Geology, School of Science, University of Sulaimani, Sulaimani, Kurdistan-Iraq \\ c Institute of Geological Sciences, Polish Academy of Sciences, 51/55 Twarda street, 00-818 Warsaw, Poland
}

Corresponding author E-mail address: k.mustafa12@imperial.ac.uk

\section{Abstract}

Black shales in the Holy Cross Mountains area of Poland provide a record of environmental change across the Ordovician-Silurian boundary. The changing depositional conditions have generated a variation in organic matter contents above and below the boundary. Investigating the organic constitution of these black shales has the potential to reveal how their organic matter contents were generated and how suitable these rocks and their lateral equivalents may be for exploitation as shale gas reservoirs. One outcrop at the Holy Cross Mountains with a continuous section across the Ordovician-Silurian boundary occurs near the village of Bardo Stawy in the Kielce region, and contains sandy-silty mudstones, as well as grey and black shales. Organic geochemical analyses of samples at Bardo Stawy reveals low Total Organic Carbon (TOC) contents for Ordovician samples and higher TOC values for Silurian samples. Organic biomarkers indicate that the Ordovician rocks were deposited in a shallow-marine shelf setting, while the Silurian rocks were deposited in a deeper marine environment. The progressive increase in TOC from the uppermost Ordovician to the lowermost Silurian rocks reflects increasingly oxygen-poor depositional conditions during the postglacial transgression. Following the deposition and preservation of organic matter in the Ordovician and Silurian rocks, these rocks were buried and subjected to thermal maturation. Rock Eval and 
Mustafa, K.A., Sephton M.A., Spathopoulos, F., Watson, J.S., Krzywiec, P. Organic geochemical characteristics of black shales across the Ordovician-Silurian boundary in the Holy Cross Mountains, Central Poland, Marine and Petroleum Geology, doi:10.1016/j.marpetgeo.2015.08.018.

biomarker thermal maturity parameters all indicate that the organic matter is mature and lies within the oil window. The Ordovician and Silurian shales have direct relevance to recent attempts to discover and exploit shale gas reservoirs in Poland. Our data and interpretations suggest that the relatively low TOC values $(<2 \%)$ and low maturities for gas generation render these rocks unsuitable for commercial shale gas production. The progressive improvement in conditions for preserving organic matter across the Ordovician-Silurian boundary does, however, leave the possibility that more suitable deposits occur in Early Silurian rocks in other parts of the basin.

\section{Introduction}

During the last ten years, there has been a substantial interest in the Ordovician and Silurian shale deposits in Europe as reservoirs for unconventional petroleum, particularly in Poland (Poprawa, 2010a). Silurian black shales, in particular, were investigated during exploration for shale oil and shale gas (Poprawa, 2010b; Poprawa and Kiersnowski, 2008). TOC content is variable within the Baltic Basin, north Poland, but a number of prerequisites for unconventional reservoirs exist (Poprawa, 2010a). Unconventional petroleum investigation initially focussed on Silurian black shales because of their relatively high TOC, laterally extensive nature, raised maturity and great thickness (Wieclaw et al., 2010). The first well in Europe that targeted an unconventional reservoir was drilled in 2011 in the Baltic Basin, north-western Poland (Boyer et al., 2011). The Early Ordovician to Early Silurian time interval represents a period of black shale deposition under stratified and anoxic bottom water conditions in many areas of North Africa, the Middle East and Europe, Fig. 1 (Berry, 2010; Leggett, 1980; Thickpenny and Leggett, 1987; Trela and Podhalanska, 2010; Wilde, 1987) including Poland (Melchin et al., 2013; Page et al., 2007). During the Ordovician-Silurian transition, there were considerable changes in the atmosphere, ocean, biosphere and, hence, in the general marine depositional conditions (Underwood et al., 1997) inextricably linked with the Late Ordovician (End Hirnantian) glacial event (Melchin et al., 2013; Sheehan, 2001). Glaciation events 
Mustafa, K.A., Sephton M.A., Spathopoulos, F., Watson, J.S., Krzywiec, P. Organic geochemical characteristics of black shales across the Ordovician-Silurian boundary in the Holy Cross Mountains, Central Poland, Marine and Petroleum Geology, doi:10.1016/j.marpetgeo.2015.08.018.

have major influence on the productivity and preservation of organic matter due to the changes in oceanic ventilation and circulation that cause oxygenation of the seawater (Berry and Wilde, 1978; Berry, 2010; Wilde, 1987). During the Ordovician-Silurian transitional period, there was a substantial change in organic matter distribution, production, and preservation on the East European Craton, particularly in Poland (Lesniewicz, 2012; Wieclaw et al., 2010). The OrdovicianSilurian boundary in Poland has been studied from several different perspectives including sedimentology (Bednarczyk and Stupnicka, 2000; Dzik and Pisera, 1994; Modlinski and Szymanski, 2001; Trela et al., 2001), palynology (Kremer, 2001; Masiak et al., 2003; Podhalanska, 2003; Trela et al., 2001), petroleum geology (Kiersnowski and Dyrka, 2013; Lesniewicz, 2012) and geochemistry (Sawlowicz and Porebska, 1998). The Holy Cross Mountains (HCM), which is located in the transition zone between Baltica and the West European Platform (Fig. 1), represents a location where Ordovician-Silurian boundary rocks are exposed, either in complete successions or as intercalations (Teller, 1988). Until now, there has been no detailed organic geochemical study of the Ordovician-Silurian boundary in the HCM. Some organic geochemistry has been performed on a few chert samples from the Silurian of the Zalesie section in the HCM (Bauersachs et al., 2009). Our current study aims to define the distribution of organic matter across the Ordovician-Silurian boundary and provides new insights into organic matter preservation at this location. The essential role of the organic matter content in defining the shale oil and shale gas potential of black shale deposits allows determination of the suitability of these rocks as shale oil and shale gas targets.

\subsection{General Geology}

\subsubsection{Ordovician}

The Ordovician-Silurian transitional sedimentary deposits are exposed in Poland only within the eastern part of the HCM (Fig. 2C) and in the Sudety Mountains, which lie west of the HCM (Podhalanska, 2003; Teller, 1988). A gradational boundary across the Ordovician-Silurian contact in the southern HCM was recognised using fossil records (Masiak et al., 2003). A complete succession 
Mustafa, K.A., Sephton M.A., Spathopoulos, F., Watson, J.S., Krzywiec, P. Organic geochemical characteristics of black shales across the Ordovician-Silurian boundary in the Holy Cross Mountains, Central Poland, Marine and Petroleum Geology, doi:10.1016/j.marpetgeo.2015.08.018.

of Ordovician and Silurian strata is preserved at Bardo Stawy (Dzik and Pisera, 1994) and a less complete succession is found at Zalesie Nowe (Masiak et al., 2003) although the precise OrdovicianSilurian boundary at these locations has not yet been determined (Kremer, 2001). Upper Ordovician deposits in the Bardo Stawy and Zalesie sections are composed of varied lithologies. These deposits comprise the Zalesie Formation, the upper parts of which are the called Zalesie Beds (Fig. 2A). The Zalesie Formation (Upper Ordovician) comprises sandstones and siltstones, dolomites and limestones, mudstones and marly mudstones (Kremer, 2001; Masiak et al., 2003). Only the uppermost Zalesie Formation rocks are exposed at the Bardo Stawy where they are six metres thick (Zalesie Beds) and are composed of green/grey sandstones and yellowish silty mudstones with shales (Masiak et al., 2003; Trela et al., 2012). These rocks were deposited during the Early Hirnantian (Latest Ordovician) regression caused by a drop in sea level that resulted from the incorporation of water in the ice caps on Gondwanaland located at the South Pole (Trela, 2007; Trela and Podhalanska, 2010). The close of the Hirnantian coincides with the appearance of light brown graptolitic shales and siltstones at the base of the Rembow Member (Fig.2A) which represent the start of a marine transgression that continued into the Early Silurian (Trela and Podhalanska, 2010). Latest Ordovician rocks in the Bardo Stawy section are well exposed in valleys and small streams, whereas they are not difficult to aaccess in the Zalesie section because of vegetation cover.

\subsubsection{Silurian}

The Bardo Stawy section (Upper Ordovician-Lower Silurian) is characterised by a continuous lithological transition (Trela et al, 2012). Black siliceous shale, grey argillaceous shale, and laminated black radiolarian cherts of the Rembow Member represent the lowermost Silurian deposits in the HCM (Kremer and Kazmierczak, 2005). The grain size change from sandy/silty to muddy deposits; and the colour change from yellow, or beige, to dark grey may also; demonstrate the appearance of reduced conditions in the Early Silurian environment (Masiak et al., 2003). The lithological change is 
Mustafa, K.A., Sephton M.A., Spathopoulos, F., Watson, J.S., Krzywiec, P. Organic geochemical characteristics of black shales across the Ordovician-Silurian boundary in the Holy Cross Mountains, Central Poland, Marine and Petroleum Geology, doi:10.1016/j.marpetgeo.2015.08.018.

consistent and coincides with the start of the proposed marine transgression at that time (Trela, 2003b). Lower Silurian sediments at Bardo Stawy are mainly graptolitic brown and black shales, as well as laminated radiolarian shales, with intercalations of sandy and marly mudstones and sandstones (Masiak et al., 2003; Trela et al., 2012). These Lower Silurian shale beds eventually pass into the Zbrza Member of the Bardo Formation (Fig. 2A). A decrease in grain size, a darkening of the colours of the sediments and a reduction in abundance of quartz grains and clasts in younger sediments suggest that the sedimentation rate progressively declined during the transition from the Ordovician to Silurian (Masiak et al., 2003). These deposits are well exposed in the stream escarpments and valleys in the Bardo Stawy section.

\section{Experimental}

\subsection{Samples}

For our investigation, 11 shale samples were collected in the Bardo Stawy outcrop from the Upper Ordovician and Lower Silurian units (Table 1 \& Fig. 2B). The Ordovician-Silurian transition in this outcrop was sampled every $20 \mathrm{~cm}$, across a two-metre span of the section. The samples were taken from the Zalesie Formation (Zalesie Beds) and Bardo Formation (Rembow Member). The boundary between Ordovician and Silurian in the Bardo Stawy section is marked by the first appearance of the graptolite Akidograptus ascensus which marks the base of the persculptus biozone and occurs at the junction between the sandy mudstones of the Zalesie Formation and the cherty shales of the Bardo Formation (Masiak et al., 2003). The Ordovician samples are composed of pale yellow, grey and dark grey silty/sandy shales and argillaceous shales. The Silurian samples consist of dark grey and black shales. About 5-10 cm of weathered rock was removed before sampling. One sample had two distinct lithologies (grey shale and silty yellow shale) and subsamples were collected and labelled as OR7a and OR7b. 
Mustafa, K.A., Sephton M.A., Spathopoulos, F., Watson, J.S., Krzywiec, P. Organic geochemical characteristics of black shales across the Ordovician-Silurian boundary in the Holy Cross Mountains, Central Poland, Marine and Petroleum Geology, doi:10.1016/j.marpetgeo.2015.08.018.

\subsection{Sample preparation and screening}

Coherent shale samples were rinsed with $n$-pentane to remove surface contamination, and then crushed to a fine powder using a pestle and mortar. Aliquots of the powdered samples were analysed for total organic carbon (TOC) using a Carlo Erba Elemental Analyzer NC2500. Carbonate was removed prior to TOC analysis by acid treatment for 24 hours followed by drying in an oven for 2 hours. Decalcified samples were then run for 6 minutes by flash combustion. About $100 \mathrm{mg}$ aliquots of each sample were also analysed by a Delsi-Nermag Rock-Eval 6 unit in which the sample was heated up to $550^{\circ} \mathrm{C}$ in a helium atmosphere. The oven was hold at $300{ }^{\circ} \mathrm{C}$ for 3 minutes and then increased at a rate of $25^{\circ} \mathrm{C} / \mathrm{min}$. In this process, the amount of free hydrocarbons (S1), the amount of hydrocarbons thermally cracked from kerogen (S2), the amount of carbon dioxide (S3) that was expelled from pyrolysis, and the temperature at which the maximum amount of S2 hydrocarbons generated $\left(\mathrm{T}_{\max }\right)$ were measured.

For extraction of hydrocarbons, known amounts (ca. $1.5 \mathrm{~g}$ ) of powdered sample were subjected to solvent extraction. An internal standard prepared from squalane and p-terphenyl were added to each sample and used for semi-quantitation. The powdered samples were placed in test tubes and a solvent mixture of dichloromethane (DCM)/methanol (95:5 v:v) was added. The mixture was then sonicated for 3 minutes, centrifuged for 5 minutes, and the supernatant was removed; the extraction process was repeated five times. After extraction, activated copper turnings were added into each sample to remove elemental sulfur and then the combined supernatants were concentrated under a stream of dry nitrogen gas. The concentrated extracts were fractionated by column chromatography using activated alumina powder in which aliphatic and aromatic fractions were eluted using hexane and DCM:hexane $(1: 1 \mathrm{v} / \mathrm{v})$, respectively, and the polar fraction was eluated using DCM:methanol $(1: 1 \mathrm{v} / \mathrm{v})$. The aliphatic and aromatic fractions were concentrated $(<0.5 \mathrm{ml})$ using dry nitrogen gas stream and were then transferred to $300 \mu \mathrm{L}$ pre-weighed insert vials where they were allowed to dry before their weights were recorded. 
Mustafa, K.A., Sephton M.A., Spathopoulos, F., Watson, J.S., Krzywiec, P. Organic geochemical characteristics of black shales across the Ordovician-Silurian boundary in the Holy Cross Mountains, Central Poland, Marine and Petroleum Geology, doi:10.1016/j.marpetgeo.2015.08.018.

\subsection{Gas chromatography-mass spectrometry (GC-MS)}

GC-MS analysis was carried out on the aliphatic and aromatic fractions of the samples using an Agilent Technologies 7890A gas chromatograph (GC) coupled to a 5975C Mass Spectrometer (MS). The GC injector was operated in a splitless mode $(1 \mu \mathrm{l})$ with a column flow rate of $1.1 \mathrm{~mL} / \mathrm{min}$. A J\&W scientific DB-5MS capillary column (30 m, $250 \mu$ m i.d., $0.25 \mu \mathrm{m}$ film thickness) was used for compound separation and helium employed as a carrier gas. The GC oven temperature was initially held at $40{ }^{\circ} \mathrm{C}$ for 2 minutes, and then raised to a $310{ }^{\circ} \mathrm{C}$ at a rate of $5^{\circ} \mathrm{C} \min ^{-1}$ where the atmosphere was held for 14 minutes. Mass spectra were acquired in electron impact mode $(70 \mathrm{eV})$ in the scan range of 50-500amu.

\subsection{Pyrolysis-GC-MS}

About 2-3 mg of solvent extracted residues was placed in pyrolysis quartz tubes using quartz wool to hold the sample in place. Pyrolysis tubes were heated by the CDS Analytical 1500 pyroprobe in its platinum coil, which was heated to $650{ }^{\circ} \mathrm{C}$ at a rate of $20^{\circ} \mathrm{C} \mathrm{ms}{ }^{-1}$ and held for 15 seconds. The pyroprobe unit was interfaced to an Agilent Technology 6890 gas chromatograph coupled to 5973 mass spectrometer (GC-MS) and the CDS Analytical 1500 interface was heated at $300{ }^{\circ} \mathrm{C}$ and held for 5 minutes. The GC injector was held at $270{ }^{\circ} \mathrm{C}$ and operated in a split mode (10:1) with column flow rate of $1.1 \mathrm{~mL} \mathrm{~min}^{-1}$. Compound separation achieved using a J\&W DB-5MS UI column (30 m length, $0.25 \mathrm{~mm}$ internal diameter and $0.25 \mathrm{um}$ film thickness). The oven was held at an initial temperature of $35^{\circ} \mathrm{C}$ for 2 minutes then ramped at a rate of $5{ }^{\circ} \mathrm{C} \min ^{-1}$ to $300{ }^{\circ} \mathrm{C}$ and held at this temperature for 8 min. Mass spectra were obtained in electron impact mode $(70 \mathrm{eV})$ using a scan range of 45 to $550 \mathrm{amu}$. 
Mustafa, K.A., Sephton M.A., Spathopoulos, F., Watson, J.S., Krzywiec, P. Organic geochemical characteristics of black shales across the Ordovician-Silurian boundary in the Holy Cross Mountains, Central Poland, Marine and Petroleum Geology, doi:10.1016/j.marpetgeo.2015.08.018.

\section{Results}

\subsection{Organic Carbon Contents}

The Upper Ordovician- Lower Silurian samples in the HCM are poor in TOC (values range from $0.07 \%$ to $1.02 \%$ ). The Ordovician samples have very low TOC content, ranging from $0.07 \%$ to $0.11 \%$ (mean $0.08 \%$ ), and the Silurian samples, however, have generally an order of magnitude higher TOC, ranging from $0.29 \%$ to $1.02 \%$ (mean $0.63 \%$ ) (Table 2 ). These TOC values were corrected to their original contents according to the equation $[\mathrm{TOCo}=\mathrm{TOCm}+(\mathrm{TOCm} *(\mathrm{Tmax}-$ 435)/30] for the samples that have Tmax higher than $435{ }^{\circ} \mathrm{C}$ (Cornford et al., 2001). Based on the TOC values the source rock quality of the Ordovician samples is "poor" $(<0.5 \%)$ and the quality of the Silurian black shales is "poor to fair" (0.5\% to $1.0 \%)$ with only one sample (BS3) showing a "good" value (1.0\% to 2.0\%) (Peters, 1986; Peters and Cassa, 1994). Owing to their low TOC values, the Ordovician samples were not analysed further by programmed pyrolysis (Rock-Eval). The TOC content increases from the Ordovician towards the Silurian boundary (Table 2). Trela and Podhalanska (2010) have found similar enrichment in TOC in the Lower Silurian shales in the Debniak 1 well (20 km north of our studied section) and the Wilkow IG1 well (20 km north-west of studied section) in the Lysogory region.

\section{2. n-Alkanes and isoprenoid hydrocarbons}

n-Alkanes and isoprenoids are similarly distributed in both Ordovician and Silurian samples (Fig. 3) though some detailed differences can be noticed. The Ordovician samples contain $n$-alkanes in the range of $n$ - $\mathrm{C}_{15}$ to $n$ - $\mathrm{C}_{20}$, except for the OR6 sample, which contains $n$-alkanes up to $n$ - $\mathrm{C}_{33}$. With the exception of OR6, the distribution of $n$-alkanes is unimodal in all Ordovician samples with a consistent maximum at $n$ - $\mathrm{C}_{17}$. The OR6 sample has a bimodal distribution with maxima at $\mathrm{C}_{17}$ and $\mathrm{C}_{26}$ with a prominence of $\mathrm{C}_{21}$ to $\mathrm{C}_{29} n$-alkanes. Trace amounts of $n$-alkylcyclohexanes from $\mathrm{C}_{15}$ to $\mathrm{C}_{19}$ with a slight predominance of odd-over-even carbon atoms were also detected. The Ordovician samples are characterised by Carbon Preference Index (CPI) (Bray and Evans, 1961) and Odd-over- 
Mustafa, K.A., Sephton M.A., Spathopoulos, F., Watson, J.S., Krzywiec, P. Organic geochemical characteristics of black shales across the Ordovician-Silurian boundary in the Holy Cross Mountains, Central Poland, Marine and Petroleum Geology, doi:10.1016/j.marpetgeo.2015.08.018.

Even Predominance (OEP) (Scalan and Smith, 1970) values ranged from 0.99 to 1.61 and 0.95 to 1.16, respectively (Table 2), which are as would be expected for high maturity samples from a time where no significant land plants existed. Isoprenoid compounds are abundant in the samples and are represented by pristane, phytane, and their $\mathrm{C}_{17}$ and $\mathrm{C}_{18}$ counterparts. The pristane/phytane ratio $(\mathrm{Pr} / \mathrm{Ph})$ in the Ordovician samples ranges from 1.53 to 4.98. $\mathrm{Pr} / n-\mathrm{C}_{17}$ values are higher than one and $\mathrm{Ph} / n-\mathrm{C}_{18}$ values are very low ranging from 0.18 to 0.94 . Terrigenous versus Aquatic Ratio (TAR) and $n-\mathrm{C}_{17} / n-\mathrm{C}_{23}$ ratios for the samples ranged from 0.07 to 3.01 and 0.44 to 5.2 , respectively (Table 2).

The ranges of $n$-alkanes vary between the Ordovician and Silurian samples (Fig. 3). The $n$-alkane distribution pattern in the Silurian samples is characterised by an abundance of $\mathrm{C}_{13}-\mathrm{C}_{33}$-alkanes with maxima at $n$ - $\mathrm{C}_{17}$. The $n$-alkane distribution is unimodal in all of the Silurian samples, but the SB1 sample is distinguished by a broad unimodal distribution, with abundant $\mathrm{C}_{15}$ to $\mathrm{C}_{30}$-alkanes and $n-\mathrm{C}_{21}$ as the most prominent $n$-alkane (Fig. 3). The CPI and OEP values of the Silurian samples are lower than those observed for the Ordovician samples, and ranged from 0.84 to 1.13 and 0.88 to 1.01, respectively, (Table 2). Relative to the Ordovician samples, the Silurian samples are characterised by a higher abundance of isoprenoids and a prominence of pristane over phytane in all samples. Compared to the Ordovician samples, lower $\mathrm{Pr} / \mathrm{Ph}$ values are observed in the Silurian samples, with a range from 1.68 to 3.46 . The $\mathrm{Pr} / n-\mathrm{C}_{17}$ values are higher than one in all the samples and $\mathrm{Ph} / n-\mathrm{C}_{18}$ values are low, except for sample SB5 which has a higher value (Table 2). Low TAR values and high $n-\mathrm{C}_{17} / n-\mathrm{C}_{23}$ values are recorded in all Silurian samples.

\subsection{Hopanes}

Hopanes are present in trace amounts in the Ordovician samples, whereas they are prominent in all Silurian samples. The hopane series exists as $C_{27}$ and $C_{29}$ to $C_{35} 17 \alpha$-21ß-hopane homologue (22R and $22 \mathrm{~S}$ epimers) in all studied samples. Identified homohopane compounds were presented in 
Mustafa, K.A., Sephton M.A., Spathopoulos, F., Watson, J.S., Krzywiec, P. Organic geochemical characteristics of black shales across the Ordovician-Silurian boundary in the Holy Cross Mountains, Central Poland, Marine and Petroleum Geology, doi:10.1016/j.marpetgeo.2015.08.018.

Table 3. The $\mathrm{C}_{30}$ hopane is the most abundant hopane in all samples apart from SB5, which has both $\mathrm{C}_{29}$ and $\mathrm{C}_{30}$ hopane hydrocarbons as the most prominent peaks (Fig. 4). Homohopanes exist in trace amounts in most of the samples including Silurian samples (Fig. 4). In addition to the hopanes, tricyclic terpanes exist in the Ordovician samples in trace amounts. The tricyclic terpanes are markedly present in all Silurian samples, where they are more abundant than the hopanes with distributions dominated by $\mathrm{C}_{20}$ to $\mathrm{C}_{28}$ compounds. This higher relative abundance of tricyclic terpanes compared to hopanes is not so prominent in the Ordovician samples with the exception of the OR10, which exhibits tricyclic relative responses similar to those in the Silurian samples (Fig. 4).

\subsection{Steranes}

The steranes exist as regular steranes and diasteranes in all samples. Regular steranes exhibit $\mathrm{C}_{21}$ to $\mathrm{C}_{22}$ and $\mathrm{C}_{27}$ to $\mathrm{C}_{29}$ compounds of $\alpha \alpha \alpha$ and $\alpha \beta \beta$ configurations with both $20 \mathrm{R}$ and $20 \mathrm{~S}$ epimers apparent. Low molecular weight steranes $\left(\mathrm{C}_{21}\right.$ pregnane and $\mathrm{C}_{22}$ homopregnane) exist as $\alpha \alpha, \alpha \beta$ and $\beta \alpha$ configurations with $\mathrm{S}$ and $\mathrm{R}$ epimers present. Detailed identifications of the sterane hydrocarbons can be found in Table 3. Pregnane is more prominent than the homopregnane in all samples. $\mathrm{C}_{27}$ to $\mathrm{C}_{29}$ diasteranes exist in almost all of the samples as $\beta \alpha$ and $\alpha \beta$ configurations (20R and 20S epimers). The $\mathrm{C}_{27}$ regular sterane occurs as the highest peak in all the samples (Fig. 5). The Ordovician samples are characterised by a high abundance of $\mathrm{C}_{27}$ regular steranes with traces, or the complete absence, of the $\mathrm{C}_{28}$ and $\mathrm{C}_{29}$ regular steranes and by a low abundance of pregnane and homopregnane steranes and diasteranes (Fig. 5). The Silurian samples display $\mathrm{C}_{27}$ regular steranes as the most prominent peak but relative to the Ordovician samples they have a notably higher responses for pregnane, homopregnane, and diasteranes (Fig. 5).

\subsection{Pyrolysates}

The results of the Py-GC-MS analysis show that the kerogen in the Ordovician samples produces only low or trace amounts of organic compounds upon pyrolysis. The Ordovician samples release small amount of $n$-alkenes/n-alkanes in a range from $\mathrm{C}_{9}$ to $\mathrm{C}_{18}$ with a maximum at $n$ - $\mathrm{C}_{16}$ (Fig. 6 ) 
Mustafa, K.A., Sephton M.A., Spathopoulos, F., Watson, J.S., Krzywiec, P. Organic geochemical characteristics of black shales across the Ordovician-Silurian boundary in the Holy Cross Mountains, Central Poland, Marine and Petroleum Geology, doi:10.1016/j.marpetgeo.2015.08.018.

Benzene, toluene, $n$-alkyl-benzenes, and $n$-di-alkyl-benzenes are also present in the pyrolysates from the Ordovician samples in low abundance but in a relatively higher proportion than the $n$-alkenes and $n$-alkanes. Aromatic compounds (naphthalene, methylnaphthalene, phenanthrene, and dibenzothiophene) exist in low amounts in the pyrolysates of all Ordovician samples (Fig. 6).

Weathering is known to remove aromatic compounds from sedimentary rocks (Marynowski et al., 2011a). The pyrolysis-GC-MS responses for the Silurian samples demonstrate that the kerogen in these samples is capable of generating hydrocarbons. The pyrolysates from the Silurian samples contain $n$-alkenes $/ n$-alkanes doublets ranging from $\mathrm{C}_{6}$ to $\mathrm{C}_{18}$, with maxima at $\mathrm{C}_{10}$ to $\mathrm{C}_{12}$. In contrast to the pyrolysis products from the Ordovician samples, ion chromatograms of $\mathrm{m} / \mathrm{z} 91$ and 92 of the Silurian pyrolysates are dominated by higher amounts and longer side chain alkyl-benzenes, as well as by responses from benzene and toluene. Naphthalene, phenanthrene, dibenzothiophene, and their alkylated counterparts are also prominent in pyrolysates of the Silurian samples (Fig. 6).

\section{Discussion}

\subsection{Origin of organic matter}

Terrigenous organic matter in the Ordovician and Early Silurian samples is not expected owing to the absence of terrestrial biomass during this part of Earth history (Grantham, 1986). Both Ordovician and Silurian samples in the HCM contain biomarkers that suggest a marine source for the organic matter owing to (i) the dominance of low molecular weight $n$-alkanes $\left(<n\right.$ - $\left.C_{23}\right)$ (Spiro et al., 1983), (ii) the unimodal distribution of $n$-alkanes in almost all of the samples (excepting samples OR6 and SB1) (Ficken et al., 2000; Gelpi et al., 1970; Tissot and Welte, 1984), (iii) high $n$ - $\mathrm{C}_{17} / n$ - $\mathrm{C}_{23}$ ratio (apart from OR6 and SB5) (Peters et al., 2005; Riboulleau et al., 2007), and (iv) a high relative abundance of $\mathrm{C}_{23}$ and low relative contents of $\mathrm{C}_{19}$ and $\mathrm{C}_{20}$ tricyclic terpanes in all samples (Ahmed et al., 2014; Peters et al., 2005; Zumberge, 1984). The organic matter in OR6 and SB5 also has marine characteristics but with slight differences compared to other samples. The following characteristics 
Mustafa, K.A., Sephton M.A., Spathopoulos, F., Watson, J.S., Krzywiec, P. Organic geochemical characteristics of black shales across the Ordovician-Silurian boundary in the Holy Cross Mountains, Central Poland, Marine and Petroleum Geology, doi:10.1016/j.marpetgeo.2015.08.018.

were observed in the Ordovician OR6 sample: (i) abundant medium to high molecular weight $n$ alkanes $\left(n\right.$ - $\mathrm{C}_{22}$ to $n$ - $\left.\mathrm{C}_{29}\right)$; (ii) a low OEP; (iii) a prominent response from $\mathrm{C}_{26} n$-alkane; and (iv) a CPI value of 1.08. The $n$-alkane distribution of the Silurian SB1 sample, on the other hand, is characterised by: (i) a broad unimodal distribution, with maxima at $n-\mathrm{C}_{21}$; (ii) a CPI value of 0.96 ; and (iii) a small OEP indicating a marine origin of organic matter. Such variations indicate that the progressive change from shallow Ordovician to deeper Silurian conditions was not accompanied by a monotonous change in organic matter content and was occasionally interrupted by variation in organic matter source. The high content of tricyclic terpanes in the Ordovician and Silurian samples (Fig. 4) demonstrates a marine origin for the organic matter, as tricyclic terpanes are absent in terrestrially-sourced organic matter (Philp and Gilbert, 1986).

Existence of $\mathrm{C}_{15}-\mathrm{C}_{22}$ n-alkanes (Fig. 3) with a low OEP (Table 2) in the samples, particularly $n$ - $\mathrm{C}_{15}, n$ $\mathrm{C}_{17}$, and $n$ - $\mathrm{C}_{19}$ in the Ordovician samples, and existence of trace amounts of $n$-alkylcyclochexanes with a slight odd-over-even predominance around $\mathrm{C}_{17}$ alkylcyclohexane (Douglas et al., 1991; Fowler, 1992; Fowler et al., 1986) are characteristic features of organic matter derived from Gloeocapsomorpha prisca algae (Hoffmann et al., 1987; Peters et al., 2005; Reed et al., 1986). Bacteriohopanepolyols, which are bacterial membrane lipids, have been considered as the precursor of hopanoid biomarkers (Ourisson and Albrecht, 1992; Ourisson et al., 1979; Ourisson and Rohmer, 1992), consistent with the high relative abundance of homohopanes $\left(\mathrm{C}_{31}-\mathrm{C}_{34}\right)$ in all samples (Fig. 4), particularly in the Silurian samples (Peters and Moldowan, 1991). Tricyclic compounds originated from algae and bacteria during the Ordovician (Moldowan et al., 1983; Ourisson et al., 1982; Zumberge, 1987). The relative abundance of regular steranes can be used as a biomarker indicator of contributing organisms and it has been suggested that the $\mathrm{C}_{27}$ sterane is sourced from marine planktons while the $\mathrm{C}_{29}$ sterane is derived from land plants (Huang and Meinschein, 1979; Volkman, 1986) or from microalgae (Volkman, 2003). As would be expected the ternary plot of steranes in the Ordovician samples reveals an abundance of $\mathrm{C}_{27}$ steranes (Fig. 7), which imply an exclusively algal 
Mustafa, K.A., Sephton M.A., Spathopoulos, F., Watson, J.S., Krzywiec, P. Organic geochemical characteristics of black shales across the Ordovician-Silurian boundary in the Holy Cross Mountains, Central Poland, Marine and Petroleum Geology, doi:10.1016/j.marpetgeo.2015.08.018.

source of organic matter while the same plot for the Silurian samples demonstrates marine-derived organic matter from both algal and bacterial sources (Fig. 7).

\subsection{Paleodepositional environments}

The $\mathrm{Pr} / \mathrm{Ph}$ ratio and the homohopane index in the Table 2 (Didyk et al., 1978; Peters et al., 2005;

Powell, 1988) suggest that the depositional environment of the organic matter was mostly suboxic, intermittently, and became anoxic for periods as a result of reintroduction of deep anoxic waters to shelf areas during Late Hirnantian sea level rise (Hammarlund et al., 2012). The interpretation of the depositional setting as generally oxic/suboxic is supported by the predominance of $\mathrm{C}_{31}$ homohopane homologue and the low content of the $\mathrm{C}_{35}$ homohopane (Peters and Moldowan, 1991). In addition, the Late Ordovician and Early Silurian sediments may have contained phosphate in their pore spaces, as indicated by the high content of $\mathrm{C}_{23}$ tricyclic terpanes and $\mathrm{C}_{31}$ and $\mathrm{C}_{32}$ extended hopanes in the Silurian samples (Fig. 4) (Zumberge, 1987). A few studies in the HCM region suggest enrichment of the environment with phosphorous as a result of microbial communities (mats) and nutrient-rich influxes from an upwelling system (Glenn et al., 1994; Kremer, 2005; Kremer and Kazmierczak, 2005; Trela, 2003a). The phosphate abundance has been suggested to form from macroaggregates on the sea floor in shallow marine environments (Kremer, 2005).

The marine depositional environment and its changes across the transition of the Ordovician to the Silurian in the samples were inferred from the TOC and biomarker data (Fig. 8). Previous investigations suggested an oxic/suboxic depositional environment for the Ordovician and less oxygenated conditions for the Silurian in the HCM, with short-term reducing conditions, in either open marine or estuarine/bay environments (Kremer, 2001; Masiak et al., 2003; Podhalanska, 2003; Trela et al., 2001). Low values of the DBT/phenanthrene ratio from pyrolysates of the samples (Table 2) are consistent with the preservation of kerogen within a marine depositional environment in the Ordovician and Silurian (Hughes et al., 1995). The distribution and abundance of the methyl- 
Mustafa, K.A., Sephton M.A., Spathopoulos, F., Watson, J.S., Krzywiec, P. Organic geochemical characteristics of black shales across the Ordovician-Silurian boundary in the Holy Cross Mountains, Central Poland, Marine and Petroleum Geology, doi:10.1016/j.marpetgeo.2015.08.018.

phenanthrenes in the Silurian samples (Fig. 6) also indicate a marine depositional environment (Budzinski et al., 1995).

The HCM area was located at the southern edge of Baltica (Fig. 1) at the end of the Ordovician (Podhalanska and Trela, 2007). At this time, the Rheic Ocean had regressed owing to the Hirnantian glaciation event (Trela, 2007) and shallow water conditions dominated in the study area (Fig. 9A). The Ordovician sediments were deposited in intra-shelf waters (Fijalkowska-Mader et al., 2010) with alternating suboxic/anoxic to oxic conditions (Trela et al., 2012). Melting of the ice caps and the resulting marine transgression in the Latest Hirnantian eventually led to deeper water conditions in the Early Silurian (Fig. 9B) and the introduction of nutrient rich waters via an upwelling system driven by the southeast trade winds (Kremer, 2005). Enhanced productivity brought about by nutrient supply would have generated oxygen depletion in the water column and therefore enhanced organic matter preservation within the pelagic or hemipelagic environment (Sawlowicz and Porebska, 1998). Enhanced preservation is consistent with TOC increase, biomarker ratios, and lithology change across the boundary (Fig 8 and Table 2). The proposal that depositional conditions changed from relatively oxic to relatively reducing across the Ordovician-Silurian boundary owing to a sea level rise (Berry, 2010; Hammarlund et al., 2012; Trela, 2007; Zhang et al., 2011), during which black graptolitic and organic rich shales were deposited, can be tested using biomarker data and the $\mathrm{Pr} / \mathrm{Ph}$ ratio and homohopane index (Fig. 8 and Table 2) that represent clear evidence of such changes (Fig. 9B).

The biomarker data in this study imply that more reduced depositional conditions during the transgression (Trela, 2003a; Trela, 2003b) are consistent with the lithological changes across the boundary; from silty/sandy claystones of the Ordovician to the black laminated shales of the Silurian (Kremer, 2001; Kremer and Kazmierczak, 2005). Our interpretations of changing conditions in the Late Ordovician and Early Silurian (Fig. 9 A\&B) in the HCM are consistent with those for the wider Ordovician-Silurian paleoenvironments. For instance, a drastic change in the 
Mustafa, K.A., Sephton M.A., Spathopoulos, F., Watson, J.S., Krzywiec, P. Organic geochemical characteristics of black shales across the Ordovician-Silurian boundary in the Holy Cross Mountains, Central Poland, Marine and Petroleum Geology, doi:10.1016/j.marpetgeo.2015.08.018.

depositional environment, bottom water condition, fossil fauna, and organic matter production and preservation was observed during the transition from the Late Ordovician to the Early Silurian, not only in Poland (Kremer, 2001; Masiak et al., 2003; Podhalanska, 2003; Sawlowicz and Porebska, 1998; Trela et al., 2001), but also in other parts of the world (Armstrong et al., 2009; Lüning et al., 2006; Melchin et al., 2013; Vecoli, 2008).

A petrological study of the Ordovician and Silurian samples (Masiak et al., 2003) reveals clay-rich rocks with little variation in mineral content across the Ordovician-Silurian boundary at Bardo Satwy. A high content of $\mathrm{C}_{31}$ homohopane (Hakimi and Abdullah, 2013) accompanied by decreasing homohopane ratios (Fig. 4), abundance of diasteranes (Fig. 5), ratio of $\mathrm{C}_{26} / \mathrm{C}_{25}$ tricyclic terpanes and ratio of $\mathrm{C}_{29} / \mathrm{C}_{30}$ hopanes are all consistent with the clay-rich character of the rocks (Peters et al., 2005; Waples and Machihara, 1991). Low ratios of DBT/Phenanthrene from the pyrolysates, Fig. 6, are also consistent with clay-rich rocks (Hughes et al., 1995).

\subsection{Weathering effects on the samples}

Published work implies that TOC $\%$ in rocks reduces by about 70 to $95 \%$ following weathering (Marynowski et al., 2011a; Wildman et al., 2004). Even after taking into account a 70 to $95 \%$ loss of TOC by weathering, the original TOC content of our samples is still far less than $2 \%$ for the Ordovician samples, whereas SB2 and SB3 Silurian samples would have original TOC percentages of about $2 \%$.

Weathering preferentially removes short chain alkanes, steranes, and some aromatic compounds, particularly methylated naphthalenes and phenanthrenes, but has lesser effects on hopanes (Clayton and King, 1987; Marynowski et al., 2011a; Marynowski et al., 2011b; Marynowski and Wyszomirski, 2008; Petsch et al., 2005; Wildman et al., 2004).

The detection of low responses for short chain alkanes and alkyl- naphthalene and phenanthrenes (Fig. 6 ) in several samples can be related to surface weathering by which these compounds were 
Mustafa, K.A., Sephton M.A., Spathopoulos, F., Watson, J.S., Krzywiec, P. Organic geochemical characteristics of black shales across the Ordovician-Silurian boundary in the Holy Cross Mountains, Central Poland, Marine and Petroleum Geology, doi:10.1016/j.marpetgeo.2015.08.018.

partially removed (Fig. 3). Thermal maturation indicators are also influenced by weathering (see below) (Table 2 and Fig. 8).

\subsection{Maturity}

In order to investigate the maturity of the samples, $T_{\max }$ values from programmed pyrolysis and several biomarker parameters were used. All samples were found to be mature for petroleum generation. Programmed pyrolysis $\mathrm{T}_{\max }$ values of the Silurian samples range from 439 to $440{ }^{\circ} \mathrm{C}$ indicating a maturity consistent with the beginning of oil window (Peters, 1986; Peters and Cassa, 1994). Isomerisation of $C_{32}$ hopane at the $C_{22}$ position and isomerisation $C_{29}$ sterane at the $C_{20}$ position, as well as Ts/Tm ratios and the $\mathrm{C}_{31}$ hopane abundance indicate a mature state for the organic matter in the samples (Peters and Moldowan, 1991; Peters et al., 2005; Seifert and Moldowan, 1980). The $\mathrm{C}_{32}$ hopane index $(22 \mathrm{~S} /(22 \mathrm{~S}+22 \mathrm{R}))$ produces high values for all samples (0.44 to 0.64$)$ indicating mature organic matter in both Ordovician and Silurian samples (Table 2). A mature state for the organic matter in all samples can also be inferred from the $C_{29}(20 S /(20 S+20 R))$ sterane index, which range from 0.54 to 0.65 (Peters et al., 2005). As Tm is unstable during diagenesis and decreases with maturity, the Ts/Tm ratio and $\mathrm{Ts} /(\mathrm{Ts}+\mathrm{Tm})$ index can also be used as maturation indicators (Seifert and Moldowan, 1978). The Ts/(Ts+Tm) index values (0.40-0.62) and the Ts/Tm values (0.67-1.66) indicate that both Ordovician and Silurian samples are mature (Table 2). The maturity data in the studied samples is consistent with the previously published maturity data from acritarchs (dark brown to black colour) (Fijalkowska-Mader et al., 2010) in the HCM. Maturity parameters exhibit some differences between the samples (Fig. 8 and Table 2) that is most likely related to differential weathering effects on the various biomarkers. For instance, steranes and some aromatic compounds are highly sensitive to weathering (Marynowski et al., 2011a; Marynowski et al., 2011b; Wildman et al., 2004). 
Mustafa, K.A., Sephton M.A., Spathopoulos, F., Watson, J.S., Krzywiec, P. Organic geochemical characteristics of black shales across the Ordovician-Silurian boundary in the Holy Cross Mountains, Central Poland, Marine and Petroleum Geology, doi:10.1016/j.marpetgeo.2015.08.018.

\section{Shale gas potential characteristics}

The shale gas potential of organic-rich shale can be assessed using several industry standards. These main standards are TOC, thermal maturity, thickness, mineralogy, kerogen type, gas-in-place, porosity, and permeability (Boyer et al., 2006; Jarvie et al., 2007). To be considered as good shale gas target a rock must satisfy a number of main prerequisites including : (1) TOC $>2.0 \%$, (2) maturity

$>0.8-1.1 \%$ Ro, (3) thickness $>15 \mathrm{~m}$, (4) clay content $<30 \%$, and (5) kerogen type II/III. Some additional requirements such as porosity $>5 \%$, permeability $>100 \mathrm{md}$, and overpressure are also taken into account (Boyer et al., 2006; Curtis and Zumberge, 2010; Jarvie et al., 2007; Kiersnowski and Dyrka, 2013; Zou et al., 2010).

For the HCM samples, the TOC content of both Ordovician and Silurian samples is far less than the $2 \%$ cut-off value (average TOC content $0.09 \%$ and $0.82 \%$ respectively). Yet the HCM rocks do have some positive qualities. The maturity of all the samples is adequate for the generation of oil and maybe some gas; the Ordovician and Silurian samples are at an early-peak maturity level that is insufficient for major gas generation. The kerogen type indicates a marine depositional environment and type II organic matter. Hence, our data and interpretations suggest that the relatively low TOC values $(<2 \%)$ and early maturities render these rocks unsuitable for commercial shale gas production. However, progressive improvement in conditions of preserving organic matter across the Ordovician-Silurian boundary does leave open the possibility that more suitable deposits of Early Silurian age may exist in other parts of the basin.

\section{Conclusions}

The study of the Ordovician-Silurian boundary in the HCM provides important information for the future unconventional petroleum exploration in this area. A substantial change during the transition from the Ordovician to Silurian in terms of organic matter content and depositional environment is inferred. The marine-derived organic matter was poorly preserved in the Ordovician samples 
Mustafa, K.A., Sephton M.A., Spathopoulos, F., Watson, J.S., Krzywiec, P. Organic geochemical characteristics of black shales across the Ordovician-Silurian boundary in the Holy Cross Mountains, Central Poland, Marine and Petroleum Geology, doi:10.1016/j.marpetgeo.2015.08.018.

because of oxic/suboxic conditions, whereas the Silurian samples are characterised by higher TOC content (than the Ordovician) preserved under reducing bottom water conditions. Weathering has affected, to some extent, the TOC \% and biomarker content of the samples. The studied samples are thermally mature with some potential for hydrocarbon generation. The changing conditions were probably related to deglaciation and sea level rise at the end of Ordovician (Latest Hirnantian) leading to higher organic matter productivity and enhanced organic preservation. While the shale samples at Bardo Stawy have poor shale oil or shale gas potential, the general improvement in conditions for organic matter production and preservation as the Ordovician transitions into the Silurian boundary suggests the possibility of more suitable deposits in lateral equivalents elsewhere in Poland.

\section{Acknowledgments}

Szymon Ostrowski (Polish Geological Institute, Warsaw) is thanked for his assistance in the field during sample collection. Karwan Mustafa thanks Ministry of Higher Education and Scientific Research of Kurdistan Regional Government (KRG) for studentship funding. Leszek Marynowski, Megan Rohrssen, and an anonymous reviewer are thanked for their comments on the manuscript.

\section{References}

Ahmed, M., Lehnert, O., Fuentes, D., Meinhold, G., 2014. Origin of oil and bitumen in the Late Devonian Siljan impact structure, central Sweden. Organic Geochemistry 68, 13-26.

Armstrong, H.A., Abbott, G.D., Turner, B.R., Makhlouf, I.M., Muhammad, A.B., Pedentchouk, N., Peters, H., 2009. Black shale deposition in an Upper Ordovician-Silurian permanently stratified, peri-glacial basin, southern Jordan. Palaeogeography, Palaeoclimatology, Palaeoecology 273, 368-377.

Bauersachs, T., Kremer, B., Schouten, S., Sinninghe Damsté, J.S., 2009. A biomarker and $\delta 15 \mathrm{~N}$ study of thermally altered Silurian cyanobacterial mats. Organic Geochemistry 40, 149-157. 
Mustafa, K.A., Sephton M.A., Spathopoulos, F., Watson, J.S., Krzywiec, P. Organic geochemical characteristics of black shales across the Ordovician-Silurian boundary in the Holy Cross Mountains, Central Poland, Marine and Petroleum Geology, doi:10.1016/j.marpetgeo.2015.08.018.

Bednarczyk, W.S., Stupnicka, E., 2000. Stratigraphy and new data on the tectonics of the Ordovician strata in the section at Miedzygrz Quarry (eastern Holy Cross Mountains, Poand). Annales Societatis Geologorum Poloniae 70, 283-297.

Berry, W.B., Wilde, P., 1978. Progressive ventilation of oceans- an explanation for the distribution of the Lower Paleozoic black shales. American Journal of Science 278, 257-275.

Berry, W.B.N., 2010. Black shales: An Ordovician perspective. Geological Society of America Special Papers 466, 141-147.

Boyer, C., Clark, B., Jochen, V., Lewis, R., Miller, C.K., 2011. Shale Gas: A Global Resource. Oilfield Review 23, 28-39.

Boyer, C., Kieschnick, J., Suarez-Rivera, R., Lewis, R.E., Waters, G., 2006. Producing Gas from its Source. Oilfield Review 18, 36-49.

Bray, E.E., Evans, E.D., 1961. Distribution of n-paraffins as a clue to recognition of source beds. Geochimica ct, Cosmochimica Aeta 22, 2-15.

Budzinski, H., Garrigues, P., Connan, J., Devillers, J., Domine, D., Radke, M., Oudins, J.L., 1995. Alkylated phenanthrene distributions as maturity and origin indicators in crude oils and rock extracts. Geochimica et Cosmochimica Acta 59, 2043-2056.

Clayton, J.L., King, J.D., 1987. Effects of weathering on biological marker and aromatic hydrocarbon composition of organic matter in Phosphoria shale outcrop. Geochimica et Cosmochimica Acta 51, 2153-2157.

Cornford, C., Burgess, C., Gliddon, T., Kelly, R., 2001. Geochemical truths in large data sets - II: Risking petroleum systems., 20th International Meeting on Organic Geochemistry, Abstract volume 1, pp. 322-323.

Curtis, J.B., Zumberge, J.E., 2010. Source rock-based evaluation of shale gas prospects, Mid-Polish and Lublin Troughs, Poland, The International Conference "Baltic-Petrol'2010", Gdańsk, Poland.

Didyk, B.M., Simoneit, B.R.T., Brassell, S.C., Eglinton, G., 1978. Organic geochemical indicators of palaeoenvironmental conditions of sedimentation. Nature 272, 216-222.

Douglas, A.G., Damsté, J.S.S., Fowler, M.G., Eglinton, T.I., de Leeuw, J.W., 1991. Unique distributions of hydrocarbons and sulphur compounds released by flash pyrolysis from the fossilised alga Gloeocapsomorpha prisca, a major constituent in one of four Ordovician kerogens. Geochimica et Cosmochimica Acta 55, 275-291.

Dzik, J., Pisera, A., 1994. Sedimentation and Fossils of the Mojcza limestone, in: Dzik, J., Olempska, E., Pisera, A. (Eds.), Ordovician carbonate platform ecosystem of the Holy Cross Mountains. Palaeontologia Polonica, pp. 5-41.

Elie, M., Faure, P., Michels, R., Landais, P., Griffault, L., 2000. Natural and Laboratory Oxidation of Low-Organic-Carbon-Content Sediments: Comparison of Chemical Changes in Hydrocarbons. Energy \& Fuels 14, 854-861.

Ficken, K.J., Li, B., Swain, D.L., Eglinton, G., 2000. An n-alkane proxy for the sedimentary input of submerged/floating freshwater aquatic macrophytes. Organic Geochemistry 31, 745-749.

Fijalkowska-Mader, A., Kuleta, M., Malec, J., Szczepanik, Z., Trela, W., Zbroja, S., Pienkowski, G., Jachowicz-Zdanowska, M., Masiak, M., Stempien-Salek, M., 2010. CIPM Field Trip Guidebook, CIMP 2010 General Meeting in Poland. Institute of Geological Sciences-Polish Academy of Sciences, Warsaw-Kielce, p. 73.

Fowler, G.M., 1992. The influence of Gloeocapsomorpha prisca on the organic geochemistry of oils and organic-rich rocks of late Ordovician age from Canada, in: Schidlowski, M., Golubic, S., Kimberley, M., McKirdy, D., Trudinger, P.A. (Eds.), Early Organic Evolution: Implications for Mineral and Energy Resources. Springer-Verlag Berlin Heidelberg, pp. 336-356.

Fowler, M.G., Abolins, P., Douglas, A.G., 1986. Monocyclic alkanes in Ordovician organic matter. Organic Geochemistry 10, 815-823.

Gelpi, E., Schneider, H., Mann, J., Oró, J., 1970. Hydrocarbons of geochemical significance in microscopic algae. Phytochemistry 9, 603-612. 
Mustafa, K.A., Sephton M.A., Spathopoulos, F., Watson, J.S., Krzywiec, P. Organic geochemical characteristics of black shales across the Ordovician-Silurian boundary in the Holy Cross Mountains, Central Poland, Marine and Petroleum Geology, doi:10.1016/j.marpetgeo.2015.08.018.

Glenn, C.R., Föllmi, K.B., Riggs, S.R., Baturin, G.N., Grimm, K.A., Trappe, J., Abed, A.M., GalliOliver, C., Garrison, R.E., Ilyan, A., Jehl, C., Rohrlich, V., Sadaqah, R.M., Schidlowski, M., Sheldon, R.E., Siegmund, H., 1994. Phosphorus and Phosphorites: Sedimentology and Environments of Formation. Eclogae geologicae Helvetiae 87, 747-788.

Grantham, P.J., 1986. The occurrence of unusual C27 and C29 sterane predominances in two types of Oman crude oil. Organic Geochemistry 9, 1-10.

Hakimi, M.H., Abdullah, W.H., 2013. Organic geochemical characteristics and oil generating potential of the Upper Jurassic Safer shale sediments in the Marib-Shabowah Basin, western Yemen. Organic Geochemistry 54, 115-124.

Hammarlund, E.U., Dahl, T.W., Harper, D.A.T., Bond, D.P.G., Nielsen, A.T., Bjerrum, C.J., Schovsbo, N.H., Schönlaub, H.P., Zalasiewicz, J.A., Canfield, D.E., 2012. A sulfidic driver for the end-Ordovician mass extinction. Earth and Planetary Science Letters 331-332, 128-139.

Hoffmann, C.F., Foster, C.B., Powell, T.G., Summons, R.E., 1987. Hydrocarbon biomarkers from Ordovician sediments and the fossil alga Gloeocapsomorpha prisca Zalessky 1917. Geochimica et Cosmochimica Acta 51, 2681-2697.

Huang, W.-Y., Meinschein, W.G., 1979. Sterols as ecological indicators. Geochemica et Cosmochimica acta 43, 739-745.

Hughes, W.B., Holba, A.G., Dzou, L.I.P., 1995. The ratios of dibenzothiophene to phenanthrene and pristane to phytane as indicators of depositional environment and lithology of petroleum source rocks. Geochimica et Cosmochimica Acta 59, 3581-3598.

Jarvie, D.M., Hill, R.J., Ruble, T.E., Pollastro, R.M., 2007. Unconventional shale-gas systems: The Mississippian Barnett Shale of north-central Texas as one model for thermogenic shale-gas assessment. AAPG Bulletin 91, 475-499.

Kiersnowski, H., Dyrka, I., 2013. Ordovician-Silurian shale gas resources potential in Poland: evaluation of Gas Resources Assessment Reports published to date and expected improvements for 2014 forthcoming Assessment. Przeglad Geologiczny 61, 639-656.

Kremer, B., 2001. Acritarchs from the Upper Ordovician of southern Holy Cross Mountains, Poland. Acta Palaeontologica Polonica 46, 595-601.

Kremer, B., 2005. Mazuelloids: Product of Post-Mortem Phosphatization of Acanthomorphic Acritarchs. Palaios 20, 27-36.

Kremer, B., Kazmierczak, J., 2005. Cyanobacterial Mats from Silurian Black Radiolarian Cherts: Phototrophic Life at the Edge of Darkness? Journal of Sedimentary Research 75, 897-906.

Leggett, J.K., 1980. British Lower Palaeozoic black shales and their palaeo-oceanographic significance. Journal of the Geological Society 137, 139-156.

Lesniewicz, J., 2012. Unconventional gas and oil-in the USA and Poland.

Lüning, S., Loydell, D.K., Štorch, P., Shahin, Y., Craig, J., 2006. Origin, sequence stratigraphy and depositional environment of an Upper Ordovician (Hirnantian) deglacial black shale, JordanDiscussion. Palaeogeography, Palaeoclimatology, Palaeoecology 230, 352-355.

Marynowski, L., Kurkiewicz, S., Rakocinski, M., Simoneit, B.R.T., 2011a. Effects of weathering on organic matter: I. Changes in molecular composition of extractable organic compounds caused by paleoweathering of a Lower Carboniferous (Tournaisian) marine black shale. Chemical Geology 285, 144-156.

Marynowski, L., Szełęg, E., Jędrysek, M.O., Simoneit, B.R.T., 2011b. Effects of weathering on organic matter: Part II: Fossil wood weathering and implications for organic geochemical and petrographic studies. Organic Geochemistry 42, 1076-1088.

Marynowski, L., Wyszomirski, P., 2008. Organic geochemical evidences of early-diagenetic oxidation of the terrestrial organic matter during the Triassic arid and semi arid climatic conditions. Applied Geochemistry 23, 2612-2618.

Masiak, M., Podhalanska, T., Stempien-Salek, M., 2003. Ordovician-Silurian boundary in the Bardo Syncline, Holy Cross Mountains, Poland-new data on fossil assemblages and sedimentary succession. Geological Quarterly 47, 311-330. 
Mustafa, K.A., Sephton M.A., Spathopoulos, F., Watson, J.S., Krzywiec, P. Organic geochemical characteristics of black shales across the Ordovician-Silurian boundary in the Holy Cross Mountains, Central Poland, Marine and Petroleum Geology, doi:10.1016/j.marpetgeo.2015.08.018.

Melchin, M.J., Mitchell, C.E., Holmden, C., Štorch, P., 2013. Environmental changes in the Late Ordovician-early Silurian: Review and new insights from black shales and nitrogen isotopes. Geological Society of America Bulletin 125, 1635-1670.

Modlinski, Z., Szymanski, B., 2001. The Silurian of the Nida, Holy Cross Mts. and Radom areas, Poland - a review. Geoloical Quaterly 45, 435-454.

Moldowan, J.M., Seifert, W.K., Gallegos, E.J., 1983. Identification of an extended series of tricyclic terpanes in petroleum. Geochimica et Cosmochimica Acta 47, 1531-1534.

Ourisson, G., Albrecht, P., 1992. Hopanoids. 1. Geohopanoids: the most abundant natural products on Earth? Accounts of Chemical Research 25, 398-402.

Ourisson, G., Albrecht, P., Rohmer, M., 1979. The Hopanoids: palaeochemistry and biochemistry of a group of natural products. Pure and Applied Chemistry 51, 709-729.

Ourisson, G., Albrecht, P., Rohmer, M., 1982. Predictive microbial biochemistry — from molecular fossils to procaryotic membranes. Trends in Biochemical Sciences 7, 236-239.

Ourisson, G., Rohmer, M., 1992. Hopanoids. 2. Biohopanoids: a novel class of bacterial lipids. Accounts of Chemical Research 25, 403-408.

Page, A.A., Zalasiewicz, J., Williams, M., Popov, L., 2007. Were transgressive black shales a negative feedback modulating glacioeustasy in the Early Palaeozoic Icehouse., in: Williams, M., Haywood, A.M., Gregory, F.J., Schmidt, D.N. (Eds.), Deep-Time Perspectives on Climate Change: Marrying the Signal from Computer Models and Biological Proxies. The Geological Society, London, pp. 123-156.

Peters, K.E., 1986. Guidelines for evaluating petroleum source rock using programmed pyrolysis. AAPG Bulletin 70, 318-329.

Peters, K.E., Cassa, M.R., 1994. Applied Source Rock Geochemistry, in: Magoon, L.B., Dow, W.G. (Eds.), The Petroleum System-From Source to Trap. AAPG Memoir 60, pp. 93-120.

Peters, K.E., Moldowan, J.M., 1991. Effects of source, thermal maturity, and biodegradation on the distribution and isomerization of homohopanes in petroleum. Organic Geochemistry 17, 47-61.

Peters, K.E., Walters, C.W., Moldowan, J.M., 2005. The Biomarker Guide: Biomarkers and isotopes in petroleum exploration and earth history. Cambridge University Press, Cambridge.

Petsch, S.T., Edwards, K.J., Eglinton, T.I., 2005. Microbial transformations of organic matter in black shales and implications for global biogeochemical cycles. Palaeogeography, Palaeoclimatology, Palaeoecology 219, 157-170.

Philp, R.P., Gilbert, T.D., 1986. Biomarker distributions in Australian oils predominantly derived from terrigenous source material. Organic Geochemistry 10, 73-84.

Podhalanska, T., 2003. Late Ordovician to Early Silurian transition and the graptolites from Ordovician/Silurian boundary near the SW rim of the East European Craton (northern Poland). In Preceedings, 7th International Graptolite Conference \& Field Meeting of International Subcommission on Silurian Stratigraphy. Serie Correlación Geológica 18, 165-171.

Podhalanska, T., Trela, W., 2007. Stratigraphy and sedimentary record of the lower Silurian succession in the southern Holy Cross Mountains, Poland. Acta Palaeontologica Sinica 46 (suppl.), 397-401.

Poprawa, P., 2010a. Shale gas and shale oil exploration in the Lower Paleozoic complex of the Baltic Basin, in: Kotarba, M., Wróbel, M. (Eds.), The International Conference "Baltic-Petrol'2010", Gdańsk, Poland.

Poprawa, P., 2010b. Shale gas potential of the Lower Palaeozoic complex in the Baltic and LublinPodlasie basins (Poland). Prezlag Geologiczny 58, 226-249.

Poprawa, P., Kiersnowski, H., 2008. Potential for shale gas and tight gas exploration in Poland. Biuletyn Panstwowego Instytutu Geologicznego 429, 145-152 (in Polish with English summary).

Powell, T.G., 1988. Pristane/phytane ratio as environmental indicator. Nature 333, 604.

Rasmussen, C.M.Ø., Harper, D.A.T., 2011. Did the amalgamation of continents drive the end Ordovician mass extinctions? Palaeogeography, Palaeoclimatology, Palaeoecology 311, 48-62. 
Mustafa, K.A., Sephton M.A., Spathopoulos, F., Watson, J.S., Krzywiec, P. Organic geochemical characteristics of black shales across the Ordovician-Silurian boundary in the Holy Cross Mountains, Central Poland, Marine and Petroleum Geology, doi:10.1016/j.marpetgeo.2015.08.018.

Reed, J.D., Illich, H.A., Horsfield, B., 1986. Biochemical evolutionary significance of Ordovician oils and their sources. Organic Geochemistry 10, 347-358.

Riboulleau, A., Schnyder, J., Riquier, L., Lefebvre, V., Baudin, F., Deconinck, J.-F., 2007. Environmental change during the Early Cretaceous in the Purbeck-type Durlston Bay section (Dorset, Southern England): A biomarker approach. Organic Geochemistry 38, 1804-1823.

Sawlowicz, Z., Porebska, E., 1998. Geochemical Study of the Ordovician/Silurian Boundary Section in Zdanow (Bardzkie Mts., Poland). Mineralogical Magazine 62A, 1326-1327.

Scalan, E.S., Smith, J.E., 1970. An improved measure of the odd-even predominance in the normal alkanes of sediment extracts and petroleum. Geochimica et Cosmochimica Acta 34, 611-620.

Seifert, W.K., Moldowan, J.M., 1980. The effect of thermal stress on source-rock quality as measured by hopane stereochemistry. Physics and Chemistry of the Earth 12, 229-237.

Seifert, W.K., Moldowan, M.J., 1978. Applications of steranes, terpanes and monoaromatics to the maturation, migration and source of crude oils. Geochimica et Cosmochimica Acta 42, 77-95.

Sheehan, P.M., 2001. The Late Ordovician Mass Extinction. Annual Review of Earth and Planetary Sciences 29, 331-364.

Spiro, B., Dinur, D., Aizenshtat, Z., 1983. Evaluation of source, environments of deposition and diagenesis of some israeli "oil shales" - N-Alkanes, fatty acids, tetrapyrroles and kerogen. Chemical Geology 39, 189-214.

Teller, L., 1988. The Ordovician-Silurian boundary in Poland. Bulletin of the British Museum Natural Histroy (Geol) 43, 93-94.

Thickpenny, A., Leggett, J.K., 1987. Stratigraphic distribution and palaeo-oceanographic significance of European early Palaeozoic organic-rich sediments, in: Brooks, J., Fleet, A.J. (Eds.), Marine Petroleum Source Rocks, pp. 231-247.

Tissot, B.P., Welte, D.H., 1984. Petroleum Formation and Occurrence, 2 ed. Springer, New York. Trela, W., 2003a. Sedimentary environment of the Ordovician phosphate-bearing sequence in central Poland. INSUGEO Serie Correlation Geologica 17, 475- 481.

Trela, W., 2003b. Sedimentological record of Oxygen-depleted conditions in Upper Ordovician of central Poland (Holy Cross Mts.). INSUGEO Serie Correlation Geologica 17, 449-455.

Trela, W., 2006. Lithostratigraphy of the Ordovician in the Holy Cross Mountains. Przeglad Geologiczny 55, 622-631(in Polish with English summary).

Trela, W., 2007. Upper Ordovician mudrock facies and trace fossils in the northern Holy Cross Mountains, Poland, and their relation to oxygen- and sea-level dynamics. Palaeogeography, Palaeoclimatology, Palaeoecology 246, 488-501.

Trela, W., Podhalanska, T., 2010. LLandovery in the Lysogory region (Holy Cross Mountains, Poland): Sedimentary record in responce to climatic and sea-level changes, in: Kotarba, M.J., Wróbel, M. (Eds.), The International Conference "Baltic-Petrol'2010”, Gdańsk, Poland, .

Trela, W., Salwa, S., 2007. Lithostratigraphy of the Lower Silurian in Bardo Stawy (southern Holy Cross Mountains): relation to sea level change and oceanographic circulation. Przeglad Geologiczny 55, 971-978.

Trela, W., Salwa, S., Marynowski, L., Pienkowski, G., Szrek, P., Malec, J., 2012. Silurian Succession of the Holy Cross Mountains, in: Institute, P.G. (Ed.), GeoShale 2012- field trip guidebook Holy Cross Mountains, Warsaw, Poland.

Trela, W., Salwa, S., Szczepanik, Z., 2001. The Ordovician rocks of Pobroszyn in the Kysogóry region of the Holy Cross Mountains, Poland. Geological Quarterly 45, 143-154.

Underwood, C.J., Crowley, S.F., Marshall, J.D., Brenchley, P.J., 1997. High-Resolution carbon isotope stratigraphy of the basal Silurian Stratotype (Dob's Linn, Scotland) and its global correlation. Journal of the Geological Society 154, 709-718.

Vecoli, M., 2008. Fossil microphytoplankton dynamics across the Ordovician-Silurian boundary. Review of Palaeobotany and Palynology 148, 91-107.

Volkman, J., 2003. Sterols in microorganisms. Appl Microbiol Biotechnol 60, 495-506. 
Mustafa, K.A., Sephton M.A., Spathopoulos, F., Watson, J.S., Krzywiec, P. Organic geochemical characteristics of black shales across the Ordovician-Silurian boundary in the Holy Cross Mountains, Central Poland, Marine and Petroleum Geology, doi:10.1016/j.marpetgeo.2015.08.018.

Volkman, J.K., 1986. A review of sterol markers for marine and terrigenous organic matter. Organic Geochemistry 9, 83-99.

Waples, D.W., Machihara, T., 1991. Biomarkers for Geologists: A Practical Guide to the Application of Steranes and Triterpanes in Petroleum Geology. AAPG, Tulsa.

Wieclaw, D., Kotarba, M.J., Kosakowski, P., Kowalski, A., Grotek, I., 2010. Habitat and hydrocarbon potential of the lower Paleozoic source rocks in the Polish part of the Baltic region. Geological Quarterly; Vol 54, No 2 (2010) 54.

Wilde, P., 1987. Model of progressive ventilation of the Late Precambrian-Early Paleozoic ocean. American Journal of Science 287, 442-459.

Wildman, R.A., Berner, R.A., Petsch, S.T., Bolton, E.W., Eckert, J.O., Mok, U., Evans, J.B., 2004. The weathering of sedimentary organic matter as a control on atmospheric O2: I. Analysis of a black shale. American Journal of Science 304, 234-249.

Zhang, T., Trela, W., Jiang, S.-Y., Nielsen, J.K., Shen, Y., 2011. Major oceanic redox condition change correlated with the rebound of marine animal diversity during the Late Ordovician. Geology.

Zou, C., Dong, D., Wang, S., Li, J., Li, X., Wang, Y., Li, D., Cheng, K., 2010. Geological characteristics and resource potential of shale gas in China. Petroleum Exploration and Development 37, 641-653.

Zumberge, J.E., 1984. Source Rocks of the La Luna Formation (Upper Cretaceous) in the Middle Magdalena Valley, Colombia, in: Palacas, J.G. (Ed.), Petroleum Geochemistry and Source Rock Potential of Carbonate Rocks. A.A.P.G. Studies in Geology, pp. 127-134.

Zumberge, J.E., 1987. Prediction of source rock characteristics based on terpane biomarkers in crude oils: A multivariate statistical approach. Geochimica et Cosmochimica Acta 51, 16251637. 
Mustafa, K.A., Sephton M.A., Spathopoulos, F., Watson, J.S., Krzywiec, P. Organic geochemical characteristics of black shales across the Ordovician-Silurian boundary in the Holy Cross Mountains, Central Poland, Marine and Petroleum Geology, doi:10.1016/j.marpetgeo.2015.08.018.

\section{Tables}

Table 1: selected samples and their sampling distance in the Bardo Stawy outcrop section in the HCM, central Poland

\begin{tabular}{|c|c|c|c|c|c|}
\hline Sample & Distance & Age & Sample & Distance & Age \\
\hline SB0 & $00 \mathrm{~cm}$ (Top) & & OR6 & 120 (Top) & \\
\hline SB1 & 20 & & OR7a & 140 & \\
\hline SB2 & 40 & & OR $7 b$ & 140 & \\
\hline SB3 & 60 & & OR8 & 160 & \\
\hline SB4 & 80 & $\Xi$ & OR9 & 180 & . \\
\hline SB5 & 100 (bottom) & $\stackrel{\Xi}{\Xi}$ & OR10 & 200 (Bottom) & Ó \\
\hline
\end{tabular}


Mustafa, K.A., Sephton M.A., Spathopoulos, F., Watson, J.S., Krzywiec, P. Organic geochemical characteristics of black shales across the Ordovician-Silurian boundary in the Holy Cross Mountains, Central Poland, Marine and Petroleum Geology, doi:10.1016/j.marpetgeo.2015.08.018.

Table 2: sample locations and their calculated biomarker parameters of the solvent extracts of the Ordovician and Silurian samples in the studied section.

\begin{tabular}{|c|c|c|c|c|c|c|c|c|c|c|c|c|}
\hline Sample & OR10 & OR9 & OR8 & OR7b & OR7a & OR6 & SB5 & SB4 & SB3 & SB2 & SB1 & SB0 \\
\hline Age (Periods) & \multicolumn{6}{|c|}{ Ordovician } & \multicolumn{6}{|c|}{ Silurian } \\
\hline Location & \multicolumn{6}{|c|}{ Bardo Stawy } & \multicolumn{6}{|c|}{ Bardo Stawy (Rembow member) } \\
\hline Distance $(\mathrm{cm})$ & 200 & 180 & 160 & 140 & 140 & 120 & 100 & 80 & 60 & 40 & 20 & 0 \\
\hline TOC $(\%)$ & 0.08 & 0.08 & 0.09 & 0.06 & 0.07 & 0.11 & 0.47 & 0.29 & 1.02 & 0.77 & 0.37 & 0.85 \\
\hline $\operatorname{Tmax}{ }^{\circ} \mathrm{C}$ & $\underline{\text { n.d. }}$ & n.d. & n.d. & n.d. & n.d. & n.d. & n.d. & n.d. & 439 & 441 & n.d. & 440 \\
\hline $\mathrm{HI}$ & n.d. & $\underline{\text { n.d. }}$. & $\underline{\text { n.d. }}$. & n.d. & $\underline{\text { n.d. }}$. & n.d. & n.d. & n.d. & 40 & 51 & n.d. & 53 \\
\hline OI & n.d. & n.d. & n.d. & n.d. & n.d. & n.d. & n.d. & n.d. & 138 & 173 & n.d. & 175 \\
\hline S1 & n.d. & n.d. & n.d. & n.d. & n.d. & n.d. & n.d. & n.d. & 0.03 & 0.03 & n.d. & 0.02 \\
\hline $\mathrm{CPI}^{\mathrm{a}}$ & 1.61 & 1.17 & 1.07 & 1.34 & 0.99 & 1.08 & 1.10 & 0.84 & 1.02 & 0.96 & 0.96 & 1.13 \\
\hline $\mathrm{OEPb}$ & 1.08 & 1.07 & 1.03 & 1.14 & 1.16 & 0.95 & 0.88 & 0.9 & 1.04 & 0.96 & 1.01 & 1.01 \\
\hline $\mathrm{Pr} / \mathrm{Ph}$ & 3.48 & 4.20 & 3.45 & 4.98 & 4.55 & 1.53 & 1.68 & 3.46 & 3.22 & 2.89 & 2.83 & 3.41 \\
\hline $\mathrm{Pr} / n-\mathrm{C}_{17}$ & 1.06 & 2.10 & 2.34 & 1.21 & 0.66 & 1.28 & 6.62 & 2.31 & 1.71 & 1.20 & 1.06 & 2.5 \\
\hline $\mathrm{Ph} / n-\mathrm{C}_{18}$ & 0.31 & 0.43 & 0.55 & 0.26 & 0.18 & 0.94 & 1.35 & 0.58 & 0.53 & 0.41 & 0.31 & 0.72 \\
\hline TAR $^{c}$ & 0.28 & 0.16 & 0.18 & 0.22 & 0.07 & 3.01 & 1.02 & 0.15 & 0.16 & 0.10 & 0.07 & 0.61 \\
\hline$n-\mathrm{C}_{17} / n-\mathrm{C}_{23}$ & 2.50 & 1.46 & 1.75 & 3.24 & 5.2 & 0.44 & 0.32 & 2.91 & 2.36 & 3.22 & 2.28 & 0.93 \\
\hline $\mathrm{C}_{23} / \mathrm{C}_{21}$ tricyclic & 0.76 & 0.66 & 0.83 & 0.91 & 0.77 & 0.33 & 1.20 & 1.35 & 1.55 & 1.12 & 1.25 & 0.98 \\
\hline Homohopane index ${ }^{d}$ & 0.06 & n.d. & n.d. & n.d. & n.d. & 0.08 & 0.09 & 0.09 & 0.13 & 0.12 & 0.43 & 0.14 \\
\hline $\mathrm{C}_{29} / \mathrm{C}_{30} \alpha \beta$ hopane & 0.90 & 1.01 & 0.81 & 0.83 & 0.83 & 0.95 & 0.77 & 0.73 & 0.74 & 0.58 & 0.53 & 0.69 \\
\hline $\mathrm{C}_{32} 22 \mathrm{~S} /(22 \mathrm{~S}+22 \mathrm{R})$ & 0.51 & 0.57 & 0.55 & 0.44 & 0.57 & 0.64 & 0.59 & 0.62 & 0.63 & 0.61 & 0.56 & 0.54 \\
\hline $\mathrm{C}_{29} \alpha \alpha \alpha 20 \mathrm{~S} /(20 \mathrm{~S}+20 \mathrm{R})$ & 0.51 & 0.25 & 0.31 & 0.38 & 0.41 & 0.48 & 0.51 & 0.51 & 0.52 & 0.52 & 0.54 & 0.5 \\
\hline $\mathrm{Ts} /(\mathrm{Ts}+\mathrm{Tm})$ & 0.40 & 0.42 & 0.53 & 0.53 & 0.52 & 0.48 & 0.62 & 0.62 & 0.62 & 0.56 & 0.50 & 0.46 \\
\hline \multicolumn{13}{|l|}{ Regular Sterane \% } \\
\hline $\mathrm{C}_{27}$ & $\underline{97.41}$ & $\underline{97.33}$ & $\underline{98.26}$ & $\underline{98.40}$ & $\underline{96.67}$ & $\underline{89.79}$ & $\underline{54.54}$ & $\underline{45.13}$ & $\underline{31.18}$ & $\underline{49.73}$ & $\underline{68.31}$ & $\underline{61.72}$ \\
\hline $\mathrm{C}_{28}$ & $\underline{1.00}$ & $\underline{1.46}$ & $\underline{0.66}$ & $\underline{0.59}$ & $\underline{2.03}$ & $\underline{3.81}$ & $\underline{22.66}$ & $\underline{23.49}$ & $\underline{30.97}$ & $\underline{15.93}$ & $\underline{10.49}$ & $\underline{8.56}$ \\
\hline $\mathrm{C}_{29}$ & $\underline{1.59}$ & $\underline{1.20}$ & $\underline{1.08}$ & $\underline{1.01}$ & $\underline{1.30}$ & $\underline{6.40}$ & $\underline{22.80}$ & $\underline{31.38}$ & $\underline{37.86}$ & $\underline{34.35}$ & $\underline{20.76}$ & $\underline{29.72}$ \\
\hline Diasterane/Sterane & 2.80 & 1.24 & 1.33 & 2.28 & 3.37 & 2.18 & 2.45 & 1.61 & 1.67 & 1.13 & 1.86 & 0.86 \\
\hline DBTf $^{f} /$ phenanthrene & 0.40 & 0.11 & 0.14 & 0.11 & 0.18 & 0.09 & 0.44 & 0.34 & 0.26 & 0.25 & 0.47 & 0.36 \\
\hline
\end{tabular}

$\underline{\text { Footnotes }}$

${ }^{a}$ Carbon Preference Index (Bray and Evans, 1961) $(\mathrm{CPI})=\left\{\left(\mathrm{C}_{25}+\mathrm{C}_{27}+\mathrm{C}_{29}+\mathrm{C}_{31}+\mathrm{C}_{33}\right) /\right.$

$\left.\left(\mathrm{C}_{24}+\mathrm{C}_{26}+\mathrm{C}_{28}+\mathrm{C}_{30}+\mathrm{C}_{32}\right)+\left(\mathrm{C}_{25}+\mathrm{C}_{27}+\mathrm{C}_{29}+\mathrm{C}_{31}+\mathrm{C}_{33}\right) /\left(\mathrm{C}_{26}+\mathrm{C}_{28}+\mathrm{C}_{30}+\mathrm{C}_{32}+\mathrm{C}_{34}\right)\right\} / 2$

${ }^{\mathrm{b}}$ Odd over Even Predominance (Scalan and Smith, 1970) $(\mathrm{OEP})=\left(\mathrm{C}_{21}+6 \mathrm{C}_{23}+\mathrm{C}_{25}\right) /\left(4 \mathrm{C}_{22}+4 \mathrm{C}_{24}\right)$

${ }^{\circ}$ Terrigenous over Aquatic Ratio (Peters et al, 2005) (TAR) $=\left(\mathrm{C}_{27}+\mathrm{C}_{29}+\mathrm{C}_{31}\right) /\left(\mathrm{C}_{15}+\mathrm{C}_{17}+\mathrm{C}_{19}\right) n-$

alkanes

${ }^{\mathrm{d}} \mathrm{C}_{35}$ Homohopane index $=\mathrm{C}_{35} /\left(\mathrm{C}_{31}+\mathrm{C}_{32}+\mathrm{C}_{33}+\mathrm{C}_{34}+\mathrm{C}_{35}\right)$

${ }^{\mathrm{e}} \mathrm{C}_{29} \beta \alpha$ Diasterane / $\mathrm{C}_{29} \alpha \alpha \alpha$ sterane

${ }^{\mathrm{f}}$ Dibenzothiophene (DBT)

n.d. : no data 
Mustafa, K.A., Sephton M.A., Spathopoulos, F., Watson, J.S., Krzywiec, P. Organic geochemical characteristics of black shales across the Ordovician-Silurian boundary in the Holy Cross Mountains, Central Poland, Marine and Petroleum Geology, doi:10.1016/j.marpetgeo.2015.08.018.

Table 3: identified peaks and their nomenclatures in the $\mathrm{m} / \mathrm{z} 191$ and 217 chromatograms of the studied samples in Bardo Stawy

\begin{tabular}{|c|c|c|}
\hline Peak label & Carbon number & Compound nomenclature \\
\hline \multicolumn{3}{|l|}{ Hopanes } \\
\hline 1 & $\mathrm{C}_{27}$ & $18 \alpha-22,29,30$-Trisnorhopane (Ts) \\
\hline 2 & $\mathrm{C}_{27}$ & $17 \alpha-22,29,30-$ Trisnorhopane (Tm) \\
\hline 3 & $\mathrm{C}_{29}$ & $17 \alpha(\mathrm{H}), 21 \beta(\mathrm{H})$-Hopane \\
\hline $3 a$ & $\mathrm{C}_{29}$ & $18 \alpha-30$-Norneohopane \\
\hline $3 b$ & $\mathrm{C}_{30}$ & $17 \alpha(\mathrm{H})$-Diahopane \\
\hline 4 & $\mathrm{C}_{30}$ & $17 \alpha(\mathrm{H}), 21 \beta(\mathrm{H})$-Hopane \\
\hline 5 & $\mathrm{C}_{31}$ & $17 \alpha(\mathrm{H}), 21 \beta(\mathrm{H})$-Hopane $(\mathrm{S}+\mathrm{R})$ \\
\hline 6 & $\mathrm{C}_{32}$ & $17 \alpha(\mathrm{H}), 21 \beta(\mathrm{H})$-Hopane $(\mathrm{S}+\mathrm{R})$ \\
\hline 7 & $\mathrm{C}_{33}$ & $17 \alpha(\mathrm{H}), 21 \beta(\mathrm{H})$-Hopane $(\mathrm{S}+\mathrm{R})$ \\
\hline 8 & $\mathrm{C}_{34}$ & $17 \alpha(\mathrm{H}), 21 \beta(\mathrm{H})$-Hopane $(\mathrm{S}+\mathrm{R})$ \\
\hline 9 & $\mathrm{C}_{35}$ & $17 \alpha(\mathrm{H}), 21 \beta(\mathrm{H})$-Hopane $(\mathrm{S}+\mathrm{R})$ \\
\hline \multicolumn{3}{|l|}{ Steranes } \\
\hline 10 & $\mathrm{C}_{21}$ & $5 \alpha(\mathrm{H}), 14 \alpha(\mathrm{H})$-Pregnane $(\mathrm{S})$ \\
\hline 11 & $\mathrm{C}_{21}$ & $5 \alpha(\mathrm{H}), 14 \alpha(\mathrm{H})$-Pregnane $(\mathrm{R})$ \\
\hline 12 & $\mathrm{C}_{21}$ & $5 \alpha(\mathrm{H}), 14 \beta(\mathrm{H})$-Pregnane $(\mathrm{S})$ \\
\hline 13 & $\mathrm{C}_{21}$ & $5 \alpha(\mathrm{H}), 14 \beta(\mathrm{H})$-Pregnane $(\mathrm{R})$ \\
\hline 14 & $\mathrm{C}_{22}$ & $5 \alpha(\mathrm{H}), 14 \beta(\mathrm{H})$-Homopregnane $(\mathrm{S})$ \\
\hline 15 & $\mathrm{C}_{22}$ & $5 \beta(\mathrm{H}), 14 \alpha(\mathrm{H})$-Homopregnane $(\mathrm{S})$ \\
\hline 16 & $\mathrm{C}_{22}$ & $5 \beta(\mathrm{H}), 14 \alpha(\mathrm{H})$-Homopregnane $(\mathrm{R})$ \\
\hline 17 & $\mathrm{C}_{22}$ & $5 \alpha(\mathrm{H}), 14 \alpha(\mathrm{H})$-Homopregnane (S) \\
\hline 18 & $\mathrm{C}_{22}$ & $5 \alpha(\mathrm{H}), 14 \beta(\mathrm{H})$-Homopregnane $(\mathrm{R})$ \\
\hline 19 & $\mathrm{C}_{27}$ & $13 \beta(\mathrm{H}), 17 \alpha(\mathrm{H})$ - Diasterane $(\mathrm{S})$ \\
\hline 20 & $\mathrm{C}_{27}$ & $13 \beta(\mathrm{H}), 17 \alpha(\mathrm{H})$ - Diasterane $(\mathrm{R})$ \\
\hline 21 & $\mathrm{C}_{27}$ & $13 \alpha(\mathrm{H}), 17 \beta(\mathrm{H})$ - Diasterane $(\mathrm{S}+\mathrm{R})$ \\
\hline 22 & $\mathrm{C}_{28}$ & $13 \beta(\mathrm{H}), 17 \alpha(\mathrm{H})-$ Diasterane $(\mathrm{S}+\mathrm{R})$ \\
\hline 23 & $\mathrm{C}_{28}$ & $13 \alpha(\mathrm{H}), 17 \beta(\mathrm{H})$ - Diasterane $(\mathrm{S}+\mathrm{R})$ \\
\hline 24 & $\mathrm{C}_{29}$ & $13 \alpha(\mathrm{H}), 17 \beta(\mathrm{H})-$ Diasterane \\
\hline 25 & $\mathrm{C}_{27}$ & $5 \alpha(\mathrm{H}), 13 \alpha(\mathrm{H}), 17 \alpha(\mathrm{H})$ - Sterane $(\mathrm{S})$ \\
\hline 26 & $\mathrm{C}_{29}$ & $13 \beta(\mathrm{H}), 17 \alpha(\mathrm{H})$ - Diasterane $(\mathrm{S})$ \\
\hline 27 & $\mathrm{C}_{27}$ & $5 \alpha(\mathrm{H}), 13 \beta(\mathrm{H}), 17 \beta(\mathrm{H})$ - Sterane $(\mathrm{S}+\mathrm{R})$ \\
\hline 28 & $\mathrm{C}_{27}$ & $5 \alpha(\mathrm{H}), 13 \alpha(\mathrm{H}), 17 \alpha(\mathrm{H})$ - Sterane $(\mathrm{R})$ \\
\hline 29 & $\mathrm{C}_{29}$ & $13 \beta(\mathrm{H}), 17 \alpha(\mathrm{H})$ - Diasterane $(\mathrm{R})$ \\
\hline 30 & $\mathrm{C}_{28}$ & $5 \alpha(\mathrm{H}), 13 \alpha(\mathrm{H}), 17 \alpha(\mathrm{H})$ - Sterane $(\mathrm{S})$ \\
\hline 31 & $\mathrm{C}_{28}$ & $5 \alpha(\mathrm{H}), 13 \beta(\mathrm{H}), 17 \beta(\mathrm{H})$ - Sterane $(\mathrm{S}+\mathrm{R})$ \\
\hline 32 & $\mathrm{C}_{28}$ & $5 \alpha(\mathrm{H}), 13 \alpha(\mathrm{H}), 17 \alpha(\mathrm{H})$ - Sterane $(\mathrm{S})$ \\
\hline 33 & $\mathrm{C}_{29}$ & $5 \alpha(\mathrm{H}), 13 \alpha(\mathrm{H}), 17 \alpha(\mathrm{H})$ - Sterane $(\mathrm{S})$ \\
\hline 34 & $\mathrm{C}_{29}$ & $5 \alpha(\mathrm{H}), 13 \beta(\mathrm{H}), 17 \beta(\mathrm{H})$ - Sterane $(\mathrm{S}+\mathrm{R})$ \\
\hline 35 & $\mathrm{C}_{29}$ & $5 \alpha(\mathrm{H}), 13 \alpha(\mathrm{H}), 17 \alpha(\mathrm{H})$ - Sterane $(\mathrm{R})$ \\
\hline
\end{tabular}


Mustafa, K.A., Sephton M.A., Spathopoulos, F., Watson, J.S., Krzywiec, P. Organic geochemical characteristics of black shales across the Ordovician-Silurian boundary in the Holy Cross Mountains, Central Poland, Marine and Petroleum Geology, doi:10.1016/j.marpetgeo.2015.08.018.

\section{Figure captions}

Figure 1: Paleogeographic reconstruction for the Late Ordovician (450 Ma) displaying the Baltic continent and the approximate location of the HCM (solid square) during the Late Ordovician, which had a shallow water environment and was influenced by an upwelling system, resulted from SE trade winds. The paleogeographic map was redrawn from R. C. Blakey maps available at http://cpgeosystems.com/mollglobe.html and the names and labels were taken from Rasmussen and Harper (2011)

Figure 2: General lithostratigraphic column (A) and simplified geological map (C) of the HCM displaying geographical location of the Bardo Stawy and sample stratigraphic locations within the sampled interval (B). SB and OR denote Silurian and Ordovician samples, respectively. The lithostratigraphic column was compiled from (Kremer, 2005; Masiak et al., 2003; Modlinski and Szymanski, 2001; Trela, 2006; Trela and Salwa, 2007) and the geological map was modified from Fijalkowska-Mader et al. (2010).

Figure 3: Partially reconstructed chromatogram $(m / z 57)$ showing the distribution of $n$-alkanes and isoprenoids in the solvent extracts of the Ordovician (OR) and Silurian (SB) samples in the HCM. The numbers above the peaks represent carbon atom numbers, Pr: Pristane, Ph: Phytane, and IS is the internal standard.

Figure 4: Partially reconstructed chromatogram $(\mathrm{m} / z$ 191) displaying the tricyclic terpanes and homohopane distribution in the extracts of some representative samples of the Ordovician (OR) and Silurian (SB) in the HCM. Carbon numbers on the peaks represent tricyclic terpane series, numbers denote homohopanes- refer to Table (3) for compound names- and IS is internal standard. 
Mustafa, K.A., Sephton M.A., Spathopoulos, F., Watson, J.S., Krzywiec, P. Organic geochemical characteristics of black shales across the Ordovician-Silurian boundary in the Holy Cross Mountains, Central Poland, Marine and Petroleum Geology, doi:10.1016/j.marpetgeo.2015.08.018.

Figure 5: Partially reconstructed chromatogram $(\mathrm{m} / z$ 217) illustrates the regular steranes and diasteranes distribution in the extracts of some representative samples of the Ordovician (OR) and Silurian (SB) samples of the HCM, Poland. Note the prominent existence of $\mathrm{C}_{27}$ regular sterane in the Ordovician samples and high abundance of diasteranes in the Silurian samples. Refer to table (3) for peak identifications.

Figure 6: Pyrograms of aromatic compounds in the pyrolysates of representative samples of the Ordovician and Silurian periods illustrates $n$-alkanes $(m / z 57)$, naphthalene and alkyl-naphthalenes $(m / z 128+142+156)$, phenanthrene $(m / z 178)$, methyl-phenanthrenes $(m / z 192)$, dibenzpthiophene $(m / z 184)$, and methyldibenzothiophenes $(m / z$ 198). Structures refer to their identified compound peaks.

Figure 7: Ternary plot of regular steranes ( $\alpha \alpha \alpha \mathrm{S}$ isomers) in the solvent extracts of Ordovician (OR) and Silurian (SB) samples in HCM showing sources of organic matter. Note the particular distribution of the Ordovician samples in the $\mathrm{C}_{27}$ corner. The diagram is modified from Huang and Meinschein (1979).

Figure 8: Stratigraphical trends of TOC percentage and some biomarker ratios displaying the change across the transition of the boundary from Ordovician into Silurian. For the legend of lithostratigraphy, refer to Figure 1.

Figure 9: Schematic model illustrates the depositional conditions, sea level, and upwelling during the Late Ordovician (A) and Early Silurian (B) for the samples in the HCM, central Poland. During the Hirnantian (A) sea level was low leading to oxic depositional conditions of the Ordovician sediments that might have been replenished by the oxygen minimum water, whereas during the Rhuddanian (B), sea level has been raised and depositional conditions were changed to suboxic/anoxic and hence shale deposition. 
Mustafa, K.A., Sephton M.A., Spathopoulos, F., Watson, J.S., Krzywiec, P. Organic geochemical characteristics of black shales across the Ordovician-Silurian boundary in the Holy Cross Mountains, Central Poland, Marine and Petroleum Geology, doi:10.1016/j.marpetgeo.2015.08.018.

\section{Figures}

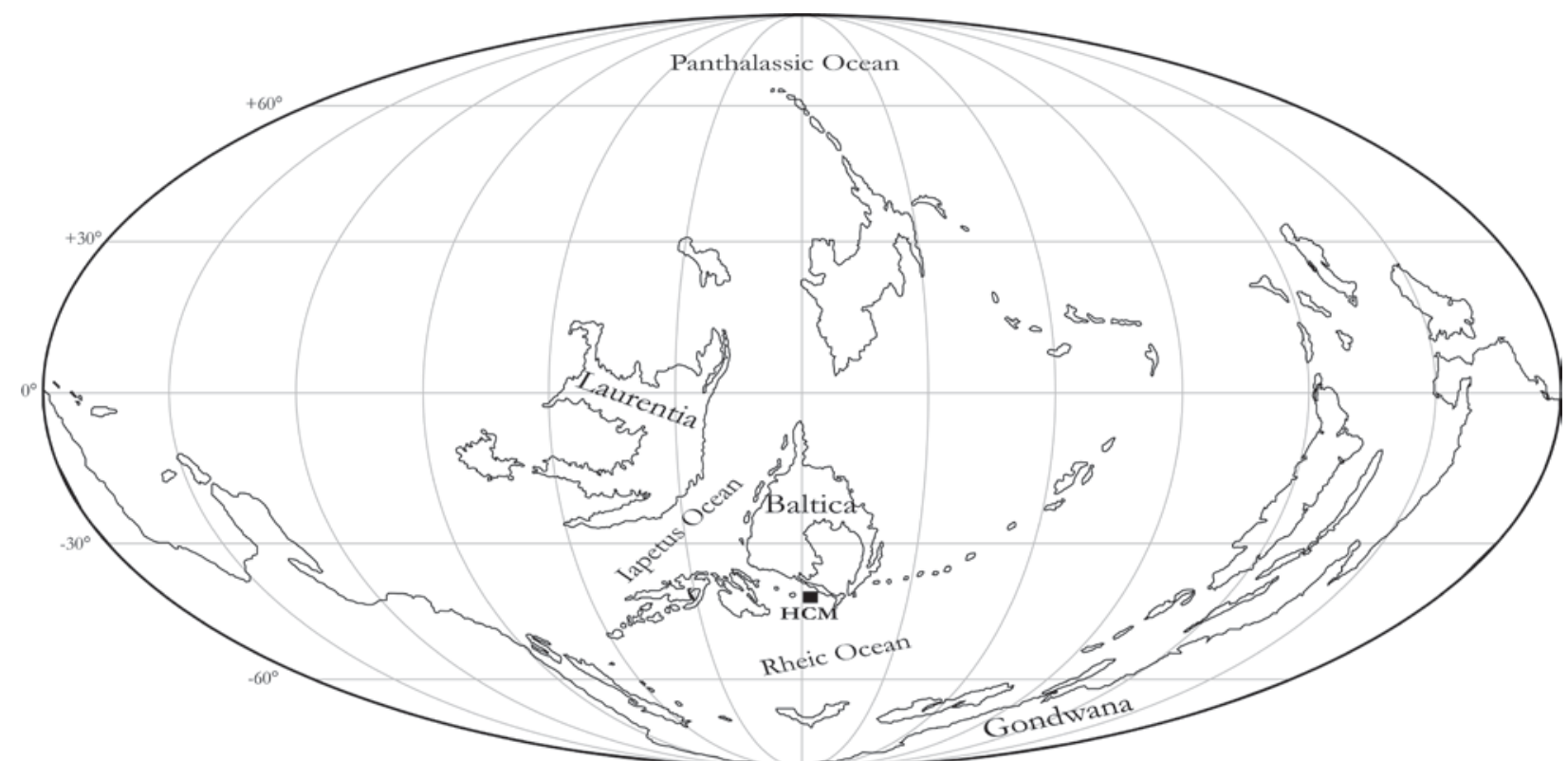

FIGURE (1) 
Mustafa, K.A., Sephton M.A., Spathopoulos, F., Watson, J.S., Krzywiec, P. Organic geochemical characteristics of black shales across the Ordovician-Silurian boundary in the Holy Cross Mountains, Central Poland, Marine and Petroleum Geology, doi:10.1016/j.marpetgeo.2015.08.018.

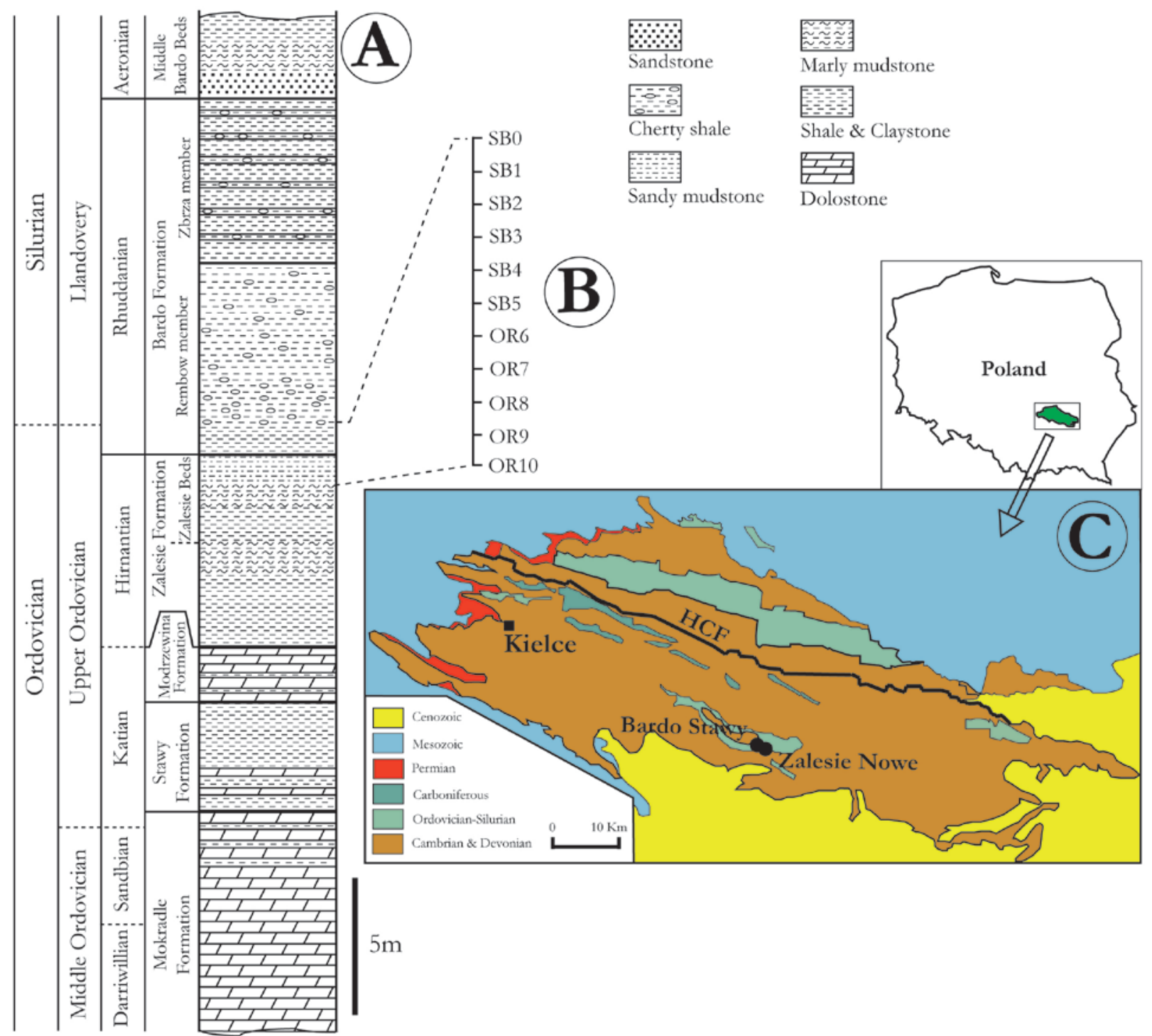

FIGURE (2) 
Mustafa, K.A., Sephton M.A., Spathopoulos, F., Watson, J.S., Krzywiec, P. Organic geochemical characteristics of black shales across the Ordovician-Silurian boundary in the Holy Cross Mountains, Central Poland, Marine and Petroleum Geology, doi:10.1016/j.marpetgeo.2015.08.018.
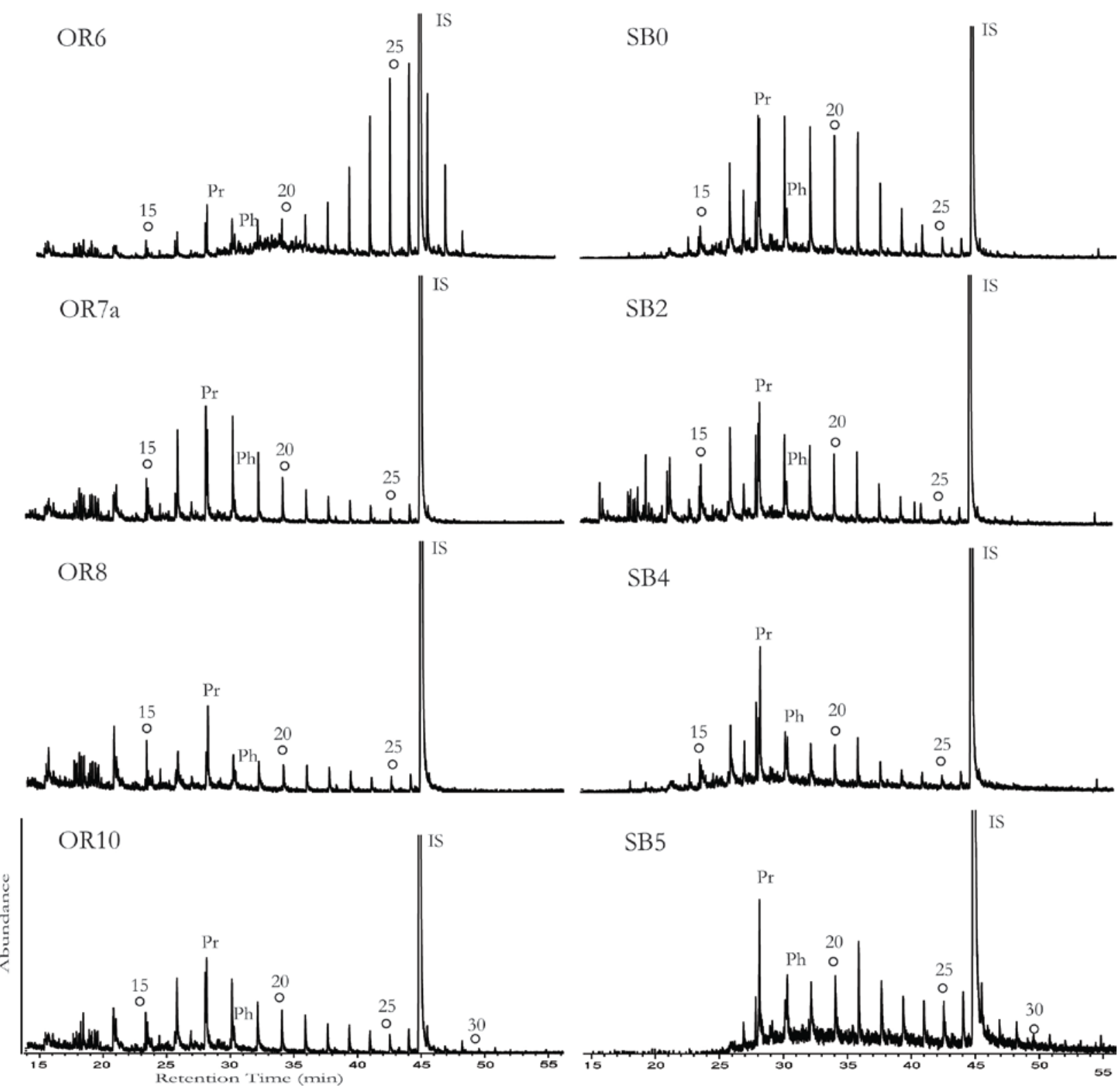

SB2

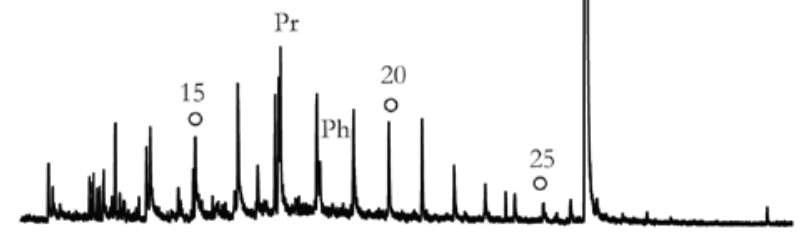

SB4

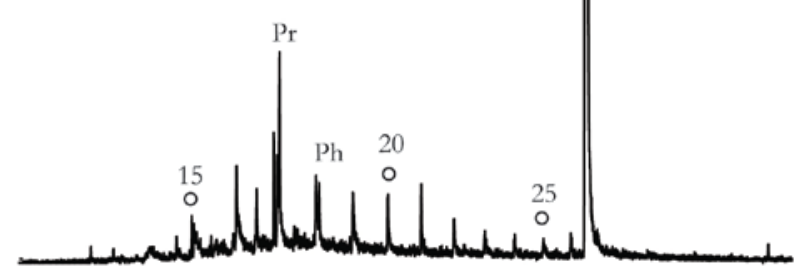

FIGURE (3)

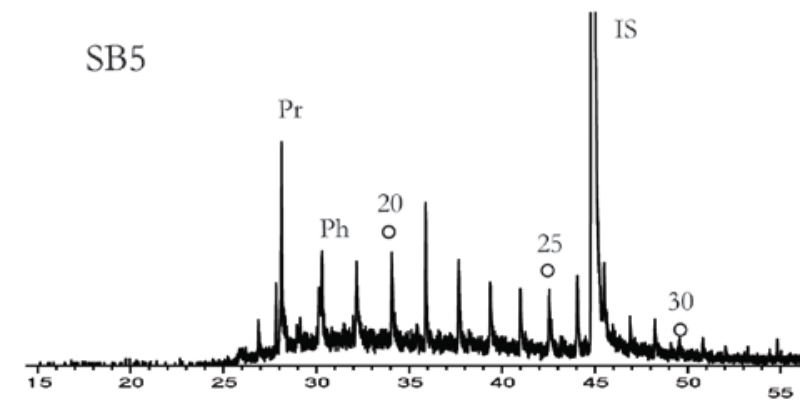


Mustafa, K.A., Sephton M.A., Spathopoulos, F., Watson, J.S., Krzywiec, P. Organic geochemical characteristics of black shales across the Ordovician-Silurian boundary in the Holy Cross Mountains, Central Poland, Marine and Petroleum Geology, doi:10.1016/j.marpetgeo.2015.08.018.

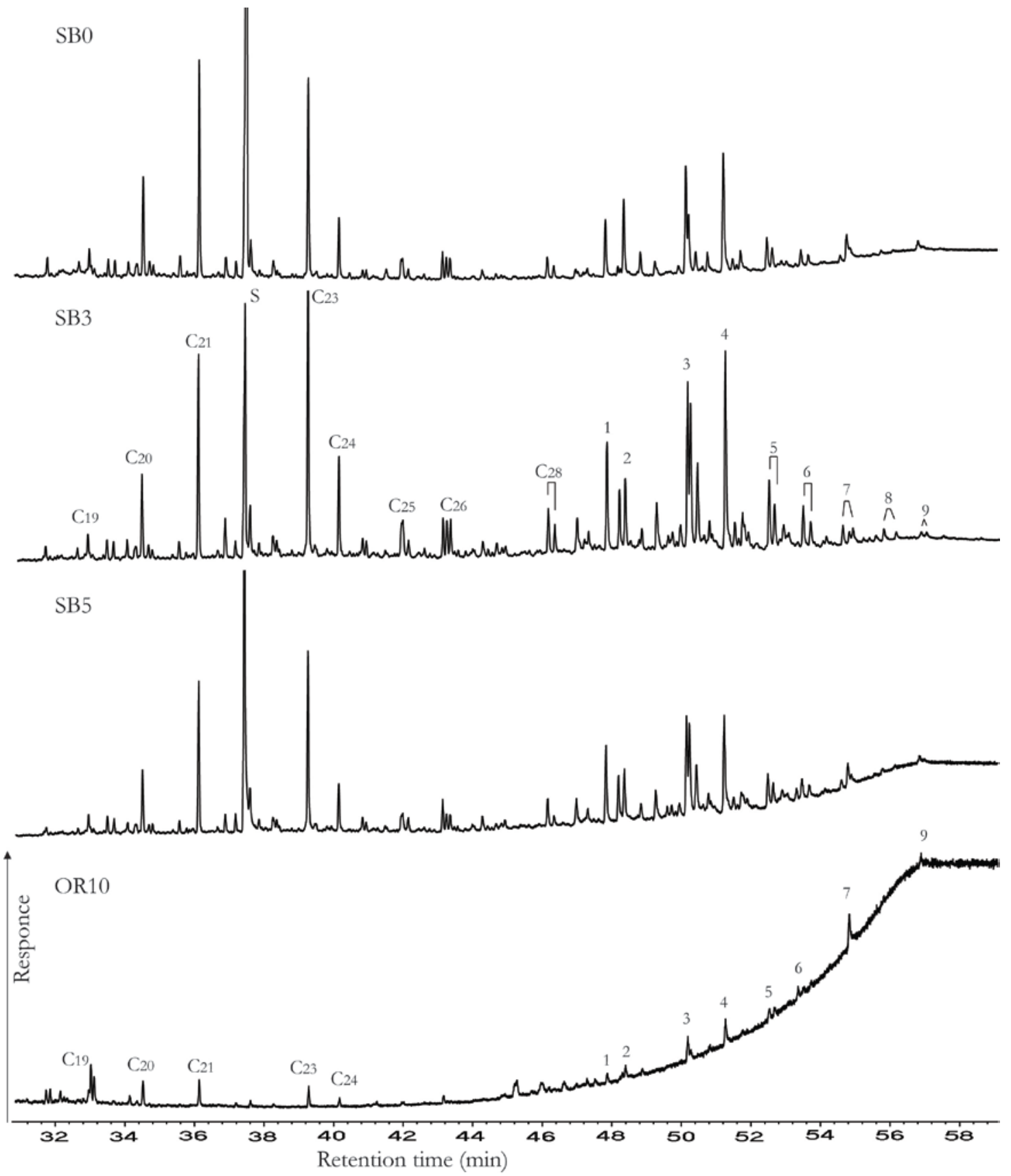

FIGURE (4) 
Mustafa, K.A., Sephton M.A., Spathopoulos, F., Watson, J.S., Krzywiec, P. Organic geochemical characteristics of black shales across the Ordovician-Silurian boundary in the Holy Cross Mountains, Central Poland, Marine and Petroleum Geology, doi:10.1016/j.marpetgeo.2015.08.018.
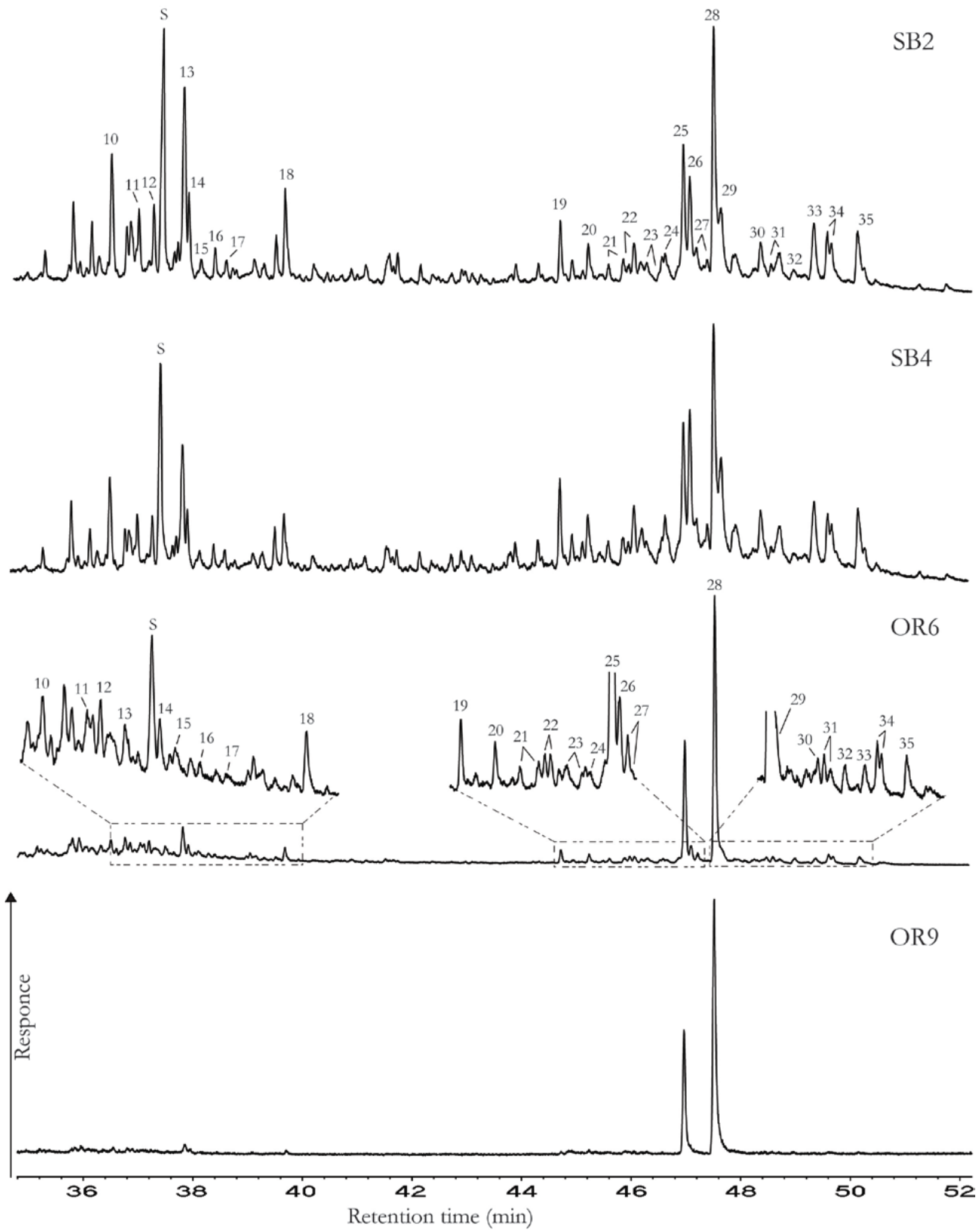

FIGURE (5) 
Mustafa, K.A., Sephton M.A., Spathopoulos, F., Watson, J.S., Krzywiec, P. Organic geochemical characteristics of black shales across the Ordovician-Silurian boundary in the Holy Cross Mountains, Central Poland, Marine and Petroleum Geology, doi:10.1016/j.marpetgeo.2015.08.018.
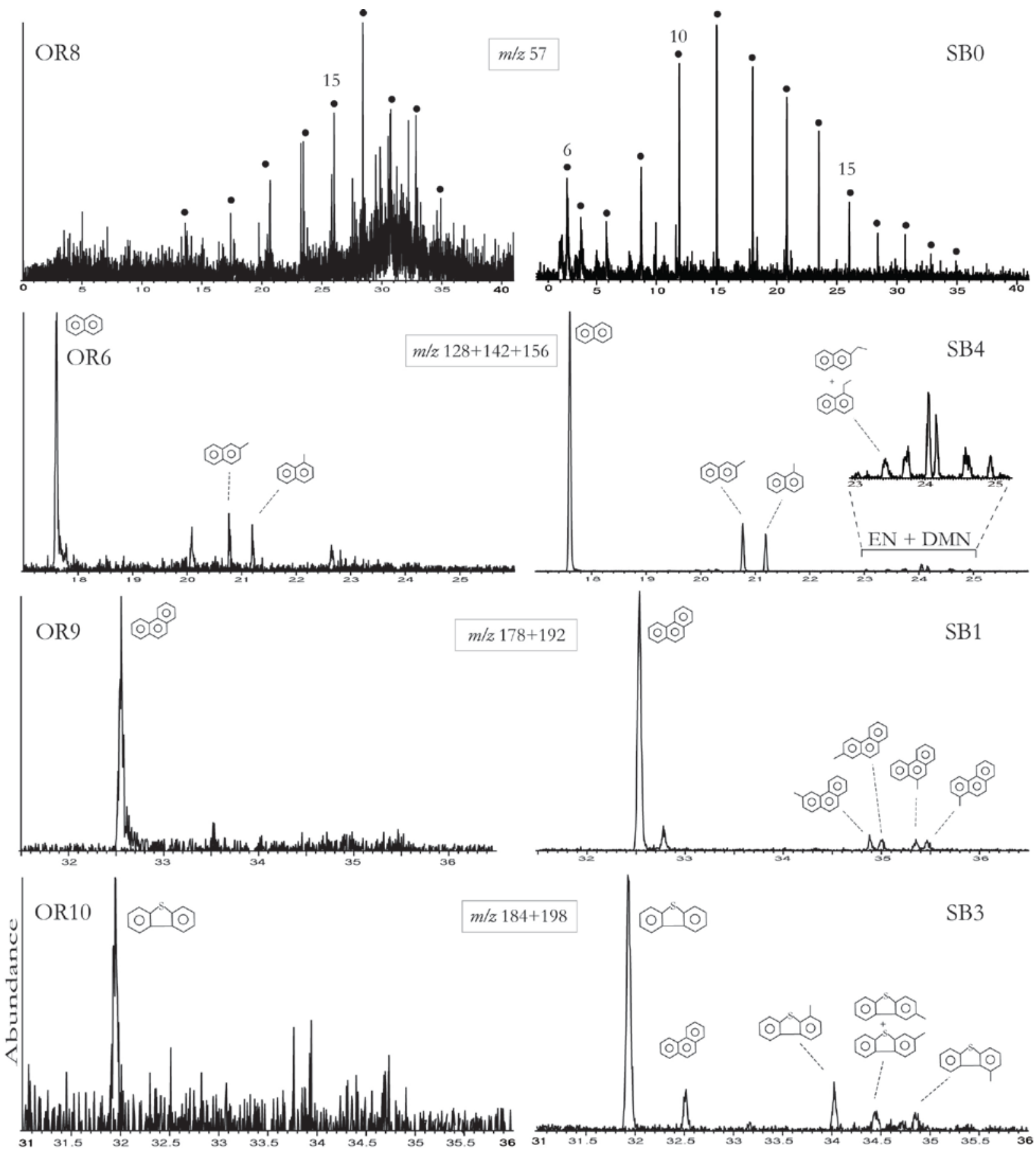

Retention Time (mins)

FIGURE (6) 
Mustafa, K.A., Sephton M.A., Spathopoulos, F., Watson, J.S., Krzywiec, P. Organic geochemical characteristics of black shales across the Ordovician-Silurian boundary in the Holy Cross Mountains, Central Poland, Marine and Petroleum Geology, doi:10.1016/j.marpetgeo.2015.08.018.

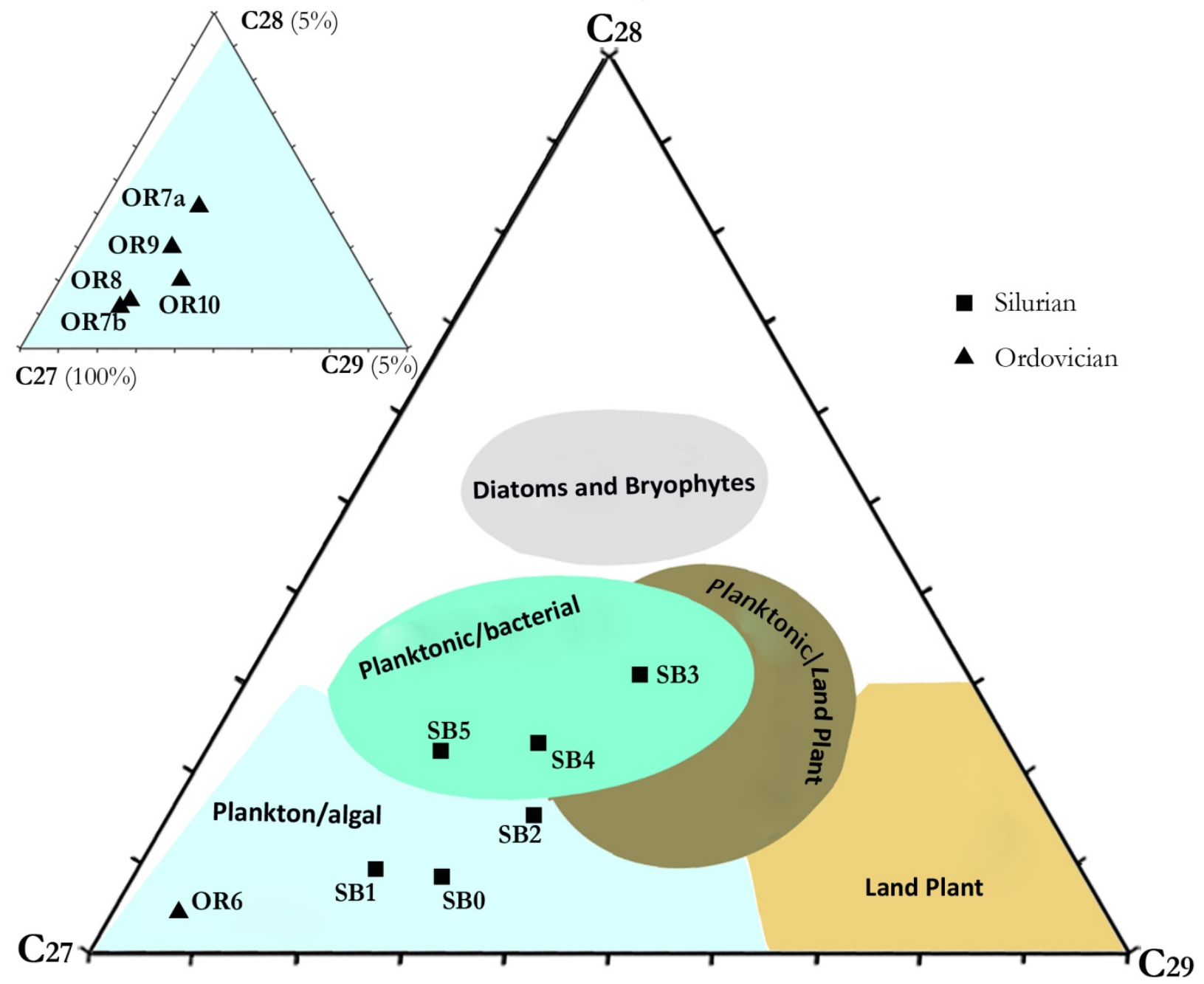

FIGURE (7) 
Mustafa, K.A., Sephton M.A., Spathopoulos, F., Watson, J.S., Krzywiec, P. Organic geochemical characteristics of black shales across the Ordovician-Silurian boundary in the Holy Cross Mountains, Central Poland, Marine and Petroleum Geology, doi:10.1016/j.marpetgeo.2015.08.018.

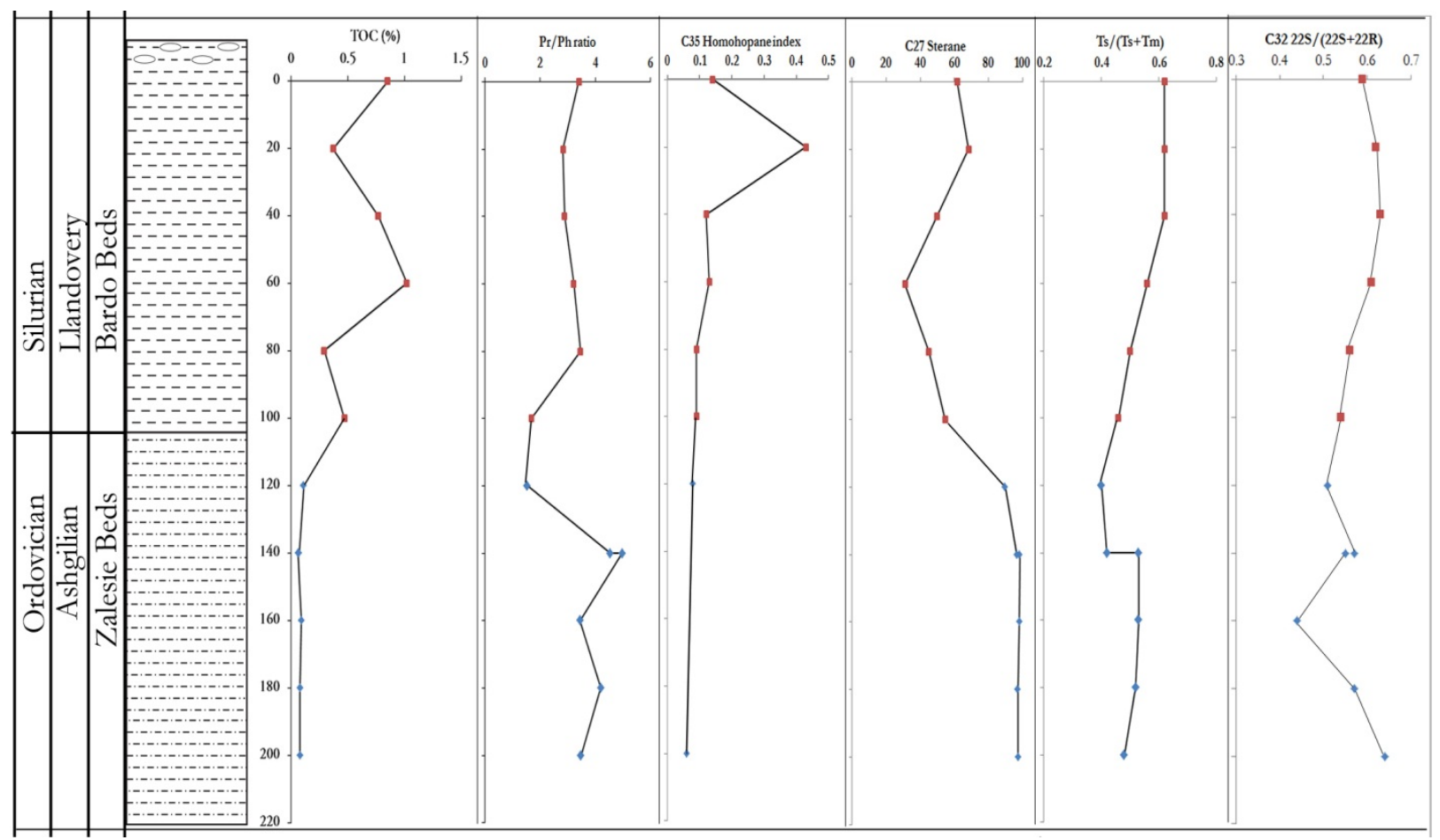

FIGURE (8) 
Mustafa, K.A., Sephton M.A., Spathopoulos, F., Watson, J.S., Krzywiec, P. Organic geochemical characteristics of black shales across the Ordovician-Silurian boundary in the Holy Cross Mountains, Central Poland, Marine and Petroleum Geology, doi:10.1016/j.marpetgeo.2015.08.018.
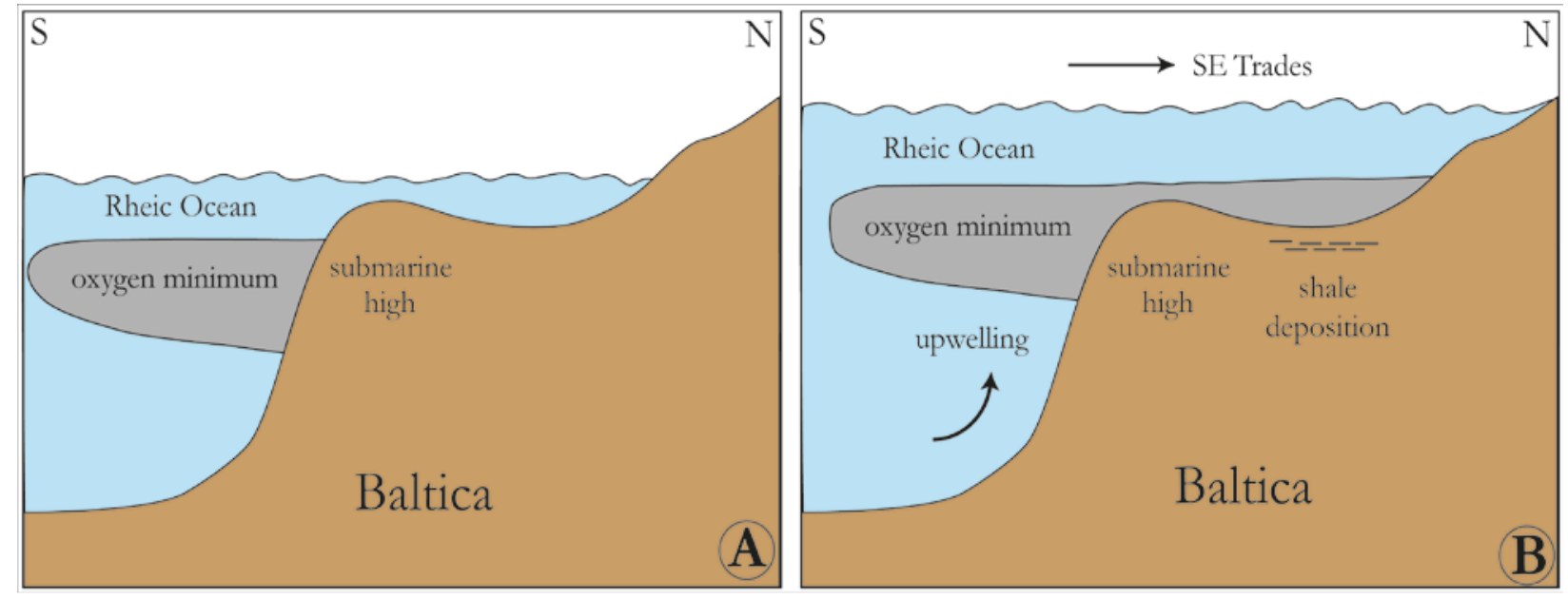

FIGURE (9) 